\title{
INSTRUMENTAL STUDY OF THE MANIX EARTHQUAKES*
}

\author{
By C. F. Richter and J. M. Nordquist \\ Data and Preliminary Investigations
}

The CIRCUMSTANCES of recording of the Manix series of earthquakes have been outlined in a preliminary report (Richter, 1947).

We now present complete data for all the thirty-four better-recorded shocks of the series, determination of epicenters and depths, and results on crustal structure and wave velocities. A favorable circumstance is the surrounding of the epicentral region by stations with sensitive Benioff vertical-component seismometers. The data of Boulder City and Pierce Ferry are of critical importance, and we are especially indebted to the U. S. Coast and Geodetic Survey for these readings. It is particularly fortunate that Pasadena, Haiwee, Boulder City, and Palomar are at roughly equal distances in different azimuths.

Unfavorable is the remoteness of the permanent stations, Riverside, the nearest, being over $130 \mathrm{~km}$. distant. This is partly compensated by overnight, runs of the portable seismometer at Old Woman Springs and Cave Mountain. Even during these runs, however, it is difficult to work with shocks of magnitude under 3.5; in general, shocks of magnitude under 4.0 cannot be used. For lesser shocks, the first motion is usually too small to be measured at some of the nearer stations; this leads to ambiguities of interpretation.

Decision to use a shock for this study has generally depended on the character of the first motion as recorded at Haiwee, the least sensitive of the nearer stations. When $\mathrm{Pn}$ is recorded at Haiwee, the first motion at Tinemaha is usually close to 13 seconds later; this serves as a check on measurement and interpretation. Often the true first motion at Haiwee was found only on careful search; it then appears as a small motion of very short period, superposed on the continuous background vibration (which has a period somewhat under one second, and is in part artificially caused). The beginning of the small $\mathrm{Pn}$, when found, is abrupt enough to be measured to the tenth of a second; this has been verified by independent measurement by the two authors.

For the Pasadena group of stations, readings are compiled from those made by three independent observers. Preliminary readings were made in the course of routine work by a very competent assistant, Mrs. Carla Maurer. Measurements were later made by the authors. Discrepancies were investigated. No readings made by any of the three observers were rejected except when manifest error was found. Where two readings by different observers, or on different records at the same station, differed by a tenth of a second the earlier was usually adopted. Details were read without close reference to expectation, and

\footnotetext{
* Manuscript received for publication June 23, 1950.
} 
no specific search was made for any phase other than the first motion at Haiwee.

Most of the shocks are referable to one of two groups, lettered A and B in the preliminary report. These have been further subdivided into A1, A2, etc. Within each subdivision, proper choice of origin times brings the travel times at any one station for the several shocks into close coincidence. The hypocenters for Group A are at the usual depth; those of Group B are nearer the surface. The designation Group $\mathrm{C}$ will be used for a few shocks with epicenters near those of Group A but with small depth like Group B. Those of Group D, from an epicenter to the southwest, are discussed as "additional shocks."

An epicenter for the main shock, No. 1, determined by the least-squares method as $34^{\circ} 58^{\prime} \mathrm{N}, 116^{\circ} 31^{\prime} .8 \mathrm{~W}$, was reported in the preliminary paper; reasons for modifying this result will be given presently. Differences of arrival times of the better-recorded aftershocks from those of the main shock at the several stations were plotted in azimuth. The sinusoidal curves resulting indicated alignment of the epicenters roughly at right angles to the strike of the Manix fault. This was confirmed by making independent least-squares solutions, from the same first-approximation epicenter as for No. 1, for the wellrecorded shocks Nos. $7,11,14,15,25$, and 27 . The seven points were plotted, and the straight line best fitting them was determined.

When a line of best fit is determined for plotted points, ordinarily one coördinate is treated as known, while the other, representing readings or measurements, is treated statistically. In fitting a straight line to points on a map both coördinates are of equal statistical value. The most probable line passes through the center of gravity of the given points. If the origin of Cartesian coördinates is moved to the center of gravity, then the slope of the required line is $\tan A$, where

$$
\left(\Sigma x^{2}-\Sigma y^{2}\right) \tan 2 A=2 \Sigma x y
$$

Calculation gave $A=-60^{\circ}$, indicating a line striking $30^{\circ}$ west of north. This work was extended to most of the shocks of table 1 . However, closer investigation of times recorded for later phases suggested that some of the differences among the shocks were due to ordinary minor errors of measurement of the first motion. Shocks were sorted into groups showing close mutual agreement; and group C, including the important shock No. 7, was established. Assuming a shock to be located on the straight line just reported on, its position along that line can be determined from the time difference between the arrivals of Pn at Haiwee and Palomar, which ranges from -1.0 to +1.2 seconds. The shocks at shallower depth, such as groups $B$ and $C$, can be identified by their early first motion at Riverside. The time difference between first motions at Mount Wilson and Riverside is near 4.5 seconds for Group A and near 5.0 seconds for Groups B and C. 
TABLE 1

Sertal Number, Date, Origin Time, and Magnitude of Shocks Studied, with Their Assignment to Groups

\begin{tabular}{l|l|l|l|l}
\hline \hline Number & Date & Origin time (P.s.T.) & Magnitude & Group \\
\hline
\end{tabular}

Shocks of the Manix series having data adequate for locations

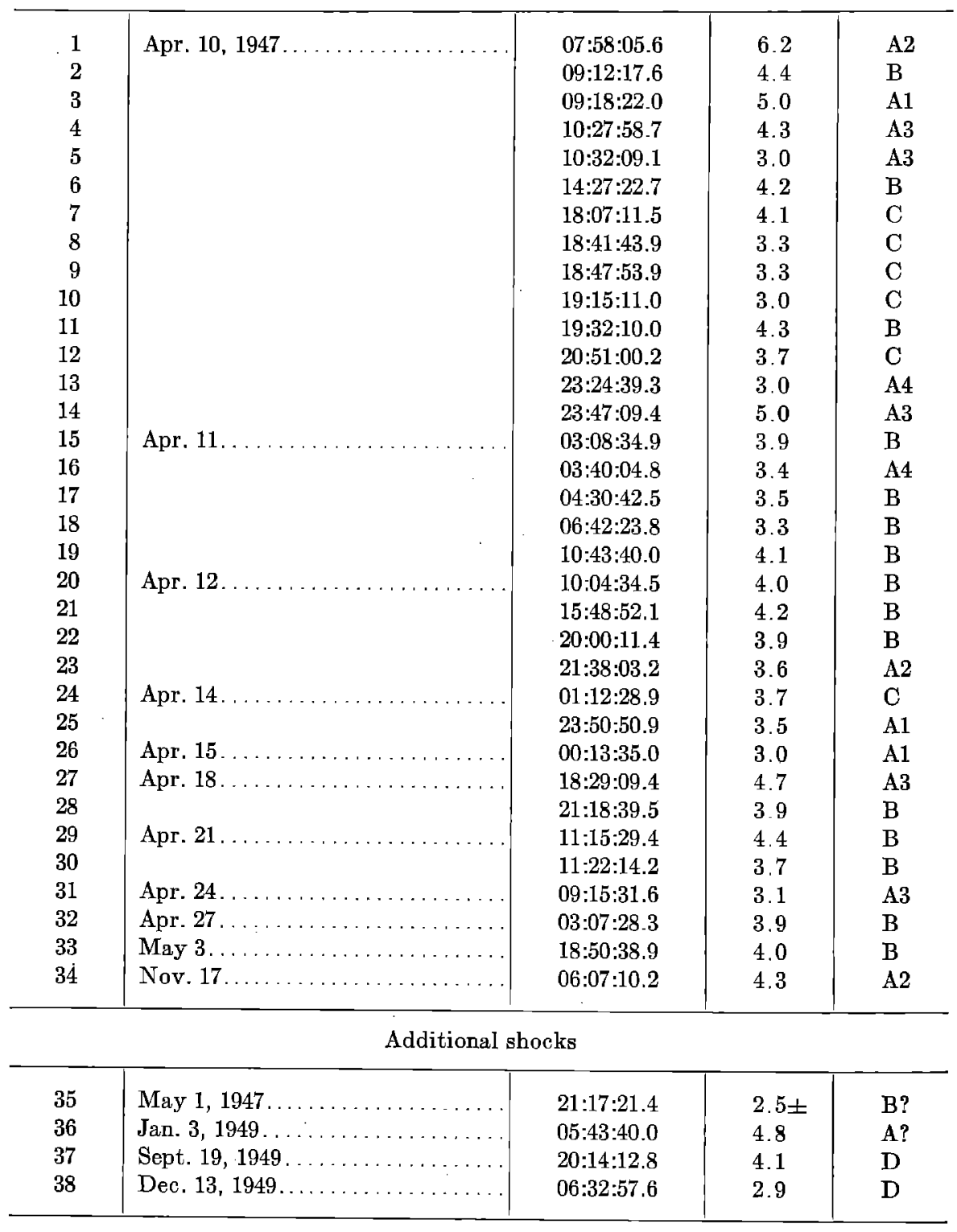


For each shock studied table 1 gives the date and adopted origin time (P.S.T.; for G.C.T. add 8 hours), the instrumental magnitude, and assignment to epicenter group A, B, C, D, or a numbered subgroup. Serial numbers in table 1 are used to identify the shocks in the other tables and in the text.

\section{REVISED INTERPRETATIONS}

In the preliminary report, and in a first draft of the present paper, readings were interpreted in terms of the travel times for southern California as determined by Gutenberg (1944), including the following equations:

$$
P n-O=6.2+0.1241 \Delta, \quad \bar{P}-O=0.1793 D, \quad D^{2}=\Delta^{2}+18^{2}
$$

With modification for the shallow depth attributed to the shocks of Groups B and $\mathrm{C}$, these were found to represent most of the data very well; however, difficulty was experienced with the times of $\bar{P}$, and in general with the first arrivals at Cave Mountain and Old Woman Springs. There were small but definite discrepancies which remained unexplained.

Subsequent to the firing of the large quarry blast at Corona, California, on August 6, 1949, Gutenberg (1951) undertook a reinterpretation of the travel times and structures. This led him to the following modifications, among others:

1) The phase $\bar{P}$, recorded at moderate distances with a velocity about 5.6 $\mathrm{km} / \mathrm{sec}$, is no longer identified as the direct wave from the hypocenter, but is believed to be a channel wave associated with a layer of relatively low velocity at a depth of the order of 15 kilometers.

2) The direct wave recorded at the shortest distances, now designated as p, has travel times nearly the same as those calculated for a constant velocity of $6.34 \mathrm{~km} / \mathrm{sec}$. and a hypocentral depth of $16 \mathrm{~km}$. The velocity named is taken to be a mean value resulting from a more complicated velocity distribution; it was determined by Richter (1950) from seven small shocks recorded in 1949 , and was verified by Gutenberg (1951) from the data of fifty other earthquakes as well as of quarry blasts. For the Lake Mead region velocities of 6.38 $\mathrm{km} / \mathrm{sec}$. for $\mathrm{p}$ and $3.75 \mathrm{~km} / \mathrm{sec}$. for s have been reported by Carder (1948).

3) For most of the shocks studied, the observations of Pn are well represented by $P n-O=K+\Delta / 8.2$ with $K=5.1$. The constant term $K$ may be expected to vary regionally, especially with differences in local structure near the epicenter, and also should increase with decreasing hypocentral depth.

Epicenters for the Manix earthquakes which had been worked out on the 1944 basis are affected very little by these modifications, since they depend chiefly on the times of Pn. For two of the shocks of Group A the readings of the temporary stations can be used as a check against the new interpretation.

The largest shock recorded at Old Woman Springs is No. 14. The best epi- 
center for this is near $34^{\circ} 58^{\prime} \mathrm{N}, 116^{\circ} 33^{\prime} \mathrm{W}$. Old Woman Springs is distant $63.0 \mathrm{~km}$., with recorded first motion at 23:14:19.7. With depth $16 \mathrm{~km}$. and velocity $6.34 \mathrm{~km} / \mathrm{sec}$, the travel time should be 10.3 seconds, making the origin time $23: 14: 09.4$. Results for the other stations are as follows:

\begin{tabular}{|c|c|c|c|c|c|}
\hline Station & $\Delta$ & $P n=23: 47$ & $\Delta / 8.2$ & $P n-\Delta / 8.2$ & $K$ \\
\hline$\ldots \ldots \ldots \ldots \ldots$ & 131.6 & 30.5 & 16.0 & 14.5 & 5.1 \\
\hline Mount Wilson... & 160.9 & 34.8 & 19.6 & 15.2 & 5.6 \\
\hline Pasadena .................. & 174.1 & 36.1 & 21.2 & 14.9 & 5.5 \\
\hline Palomar. . . . . . . . . . . . . & 181.6 & 37.2 & 22.1 & 15.1 & 5.5 \\
\hline Haiwee... & 182.5 & 37.2 & 22.3 & 14.9 & 5.3 \\
\hline Boulder City...... & 192.2 & 38.1 & 23.4 & 14.7 & 5.2 \\
\hline La Jolla. . & 242.2 & 44.7 & 29.5 & 15.2 & 5.8 \\
\hline Overton. . & 257.9 & 46.5 & 31.5 & 15.0 & 5.6 \\
\hline Pierce Ferry . . . . . . . . . . . & 264.0 & 47.4 & 32.2 & 15.2 & 5.8 \\
\hline Tinemaha $\ldots \ldots \ldots \ldots \ldots \ldots$ & 281.9 & 50.2 & 34.4 & 15.8 & 6.2 \\
\hline Santa Barbara. & 295.8 & 51.3 & 36.1 & 15.2 & 5.8 \\
\hline Berkeley . . . . . . . . . . . . . & 605.2 & 89.9 & 73.8 & 16.1 & 6.7 \\
\hline Tucson.... & 610.1 & 89.3 & 74.4 & 14.9 & 5.4 \\
\hline
\end{tabular}

$K$ is the constant term in the equation for the travel time of $\mathrm{Pn}$. It is found here by subtracting from $P n-\Delta / 8.2$ the origin time (09.4), and a further correction for the height of the station above sea level; this correction is $0.2 \mathrm{sec}$. for Mount Wilson, Palomar, Haiwee, and Tinemaha, and 0.1 sec. for Boulder City and Tueson.

The only large shock recorded at Cave Mountain is No. 25. The chosen epicenter is $34^{\circ} 57^{\prime} .5 \mathrm{~N}, 116^{\circ} 32^{\prime} \mathrm{W}$. Cave Mountain is distant $21.6 \mathrm{~km}$., with first motion at 23:50:55.2. With depth $16 \mathrm{~km}$. and velocity $6.34 \mathrm{~km} / \mathrm{sec}$., the travel time should be 04.3 sec., giving as origin time $23: 50: 50.9$. For the other stations we find:

\begin{tabular}{|c|c|c|c|c|c|}
\hline Station & $\Delta$ & $P_{n}=23: 51$ & $\Delta / 8.2$ & $P n-\Delta / 8.2$ & $K$ \\
\hline Riverside. & 132.1 & 12.1 & 16.1 & 56.0 & 5.1 \\
\hline Mount Wilson. & 161.7 & 16.4 & 19.4 & 56.7 & 5.5 \\
\hline Pasadena................... & 175.2 & 17.7 & 21.4 & 56.3 & 5.4 \\
\hline Palomar..... & 180.9 & 18.5 & 22.1 & 56.4 & 5.3 \\
\hline$\ldots \ldots \ldots \ldots \ldots$ & 184.2 & 19.0 & 22.5 & 56.5 & 5.4 \\
\hline Boulder City . . . . . . . . . . . . & 191.5 & 19.7 & 23.4 & 56.3 & 5.3 \\
\hline Overton .................. & 257.4 & 27.7 & 31.4 & 56.3 & 5.4 \\
\hline Pierce Ferry . . . . . . . . . . . . . & 263.1 & $29.0 \pm$ & 32.1 & $56.9 \pm$ & $6.0 \pm$ \\
\hline Tinemaha . . . . . . . . . . . . . . & 283.5 & 31.9 & 34.6 & 57.3 & 6.2 \\
\hline Tucson. . & 608.5 & 70.4 & 74.2 & 56.2 & 5.2 \\
\hline
\end{tabular}

Pn for No. 25 is not recorded at La Jolla or Santa Barbara; the first legible motions there are much later.

The values of $K$ calculated from the two shocks agree closely, not merely in 
the mean, but for the individual stations. Most of the deviations from the mean are probably significant. Rejecting Riverside and Tinemaha, the mean value of $K$ including both shocks is 5.5. Since this includes possibly late readings at the less sensitive stations La Jolla and Santa Barbara, and a less positive late reading at Pierce Ferry, a slightly smaller value will be adopted in further work, and we shall take for shocks of Group A

$$
P n-O=5.4+\Delta / 8.2
$$

Origin times given for these shocks in table 1, and used in finding the travel times in following tables, are adjusted primarily on this basis, with further attention to the entire series of observed times for each shock.

Comparable agreement between the two sets of data could be obtained with difficulty, if at all, using the 1944 travel times. If for No. 25 we suppose a depth of $18 \mathrm{~km}$. and a velocity of $5.55 \mathrm{~km} /$ sec., the travel time to Cave Mountain should be 5.1 sec. instead of 4.3. This would increase the computed $K$ from 5.4 to 6.2 sec., in agreement with the 1944 travel times. However, if we now apply the same $K$ to No. 14, the travel time to Old Woman Springs becomes 11.1 sec., which is impossibly short on this basis $(5.55 \mathrm{~km} / \mathrm{sec}$. and depth of $18 \mathrm{~km}$. give a travel time of $11.8 \mathrm{sec}$.). If we attempt to remove the discrepancy by taking the origin time 0.7 sec. earlier, the computed $K$ will be increased by the same amount, and we must suppose a hypocentral depth of about $13 \mathrm{~km}$. The newly revised times call for no such difference in depth between the two shocks.

The early first arrival at Riverside probably is not Pn, but $p$. The calculated travel time of $\mathrm{p}$ for $132 \mathrm{~km}$. is $21.0 \mathrm{sec}$. The observed travel times in the two shocks are 21.1 and 21.2 sec. As shown in table 3 , No. 25 has a distinct phase 0.3 sec. later. A similar sharp impulse exists on the seismograms of No. 14. These would fit the expected Pn.

The late arrival of Pn at Tinemaha probably represents the delaying effect of the margin of the "root" of the Sierra Nevada. The record at Berkeley clearly begins late, and comparison with the main shock suggests that this is due to the same cause.

Satisfactory agreement of the Tucson readings with those of other stations depends on using the apparent velocity $8.2 \mathrm{~km} / \mathrm{sec}$. for Pn. Preliminary work was done using $8.1 \mathrm{~km} / \mathrm{sec}$, with the result that the first motion at Tucson was nearly 1 sec. earlier than the calculated time; this suggested a shift of the epicenter which was hard to reconcile with the data of other stations. The revised velocity partly explains the modified epicenter now adopted for the main shock. The true velocity below the Mohorovičic discontinuity must be smaller than this; but there is indication that 8.2 is a little too large even for the apparent velocity. 


\section{TABLE 2}

Observed Travel Times of Manix Shocks, Group A1

(Serial numbers and origin times are as given in table 1. Epicenter $34^{\circ} 57 ! 5 \mathrm{~N}$, $116^{\circ} 32^{\prime} \mathrm{W} . h=16 \mathrm{~km}$.)

\begin{tabular}{|c|c|c|c|}
\hline Station & $\underset{(\mathrm{km} .)}{\text { Distance }}$ & $\begin{array}{c}\text { Shack } \\
\text { no. }\end{array}$ & Travel times (sec.) \\
\hline Cave Mountain. & 21.6 & $\begin{array}{l}25 \\
26\end{array}$ & $\begin{array}{lll}04.3 & & \\
04.4 & 06.7 & 07.9\end{array}$ \\
\hline Riverside.... . & 132.1 & $\begin{array}{r}3 \\
25 \\
26\end{array}$ & $\begin{array}{llllll}21.0 & 21.5 & 35.8 & 38.3 & 39.7 \\
21.2 & 21.5 & 22.6 & 35.9 & 37.2 \\
21.1 & 35.7 & 36.2 & & \end{array}$ \\
\hline Mount Wilson. . & 161.7 & $\begin{array}{r}3 \\
25 \\
26\end{array}$ & 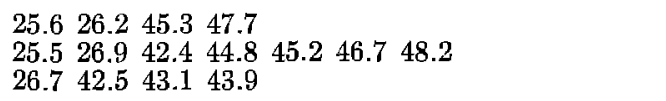 \\
\hline Pasadena.. & 175.2 & $\begin{array}{r}3 \\
25 \\
26\end{array}$ & $\begin{array}{llllllll}27.0 & 27.8 & 28.2 & 29.4 & 31.2 & 40.5 & 49.0 & \\
26.8 & 27.5 & 28.4 & 34.5 & 36.9 & 40.9 & 45.6 & 47.5 \\
27.6 & 28.5 & 31.3 & 46.4 & 47.6 & 49.0 & 49.8\end{array}$ \\
\hline Palomar. . & 180.9 & $\begin{array}{r}3 \\
25 \\
26\end{array}$ & 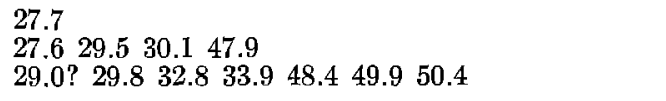 \\
\hline Haiwee. & 184.2 & $\begin{array}{r}3 \\
25 \\
26\end{array}$ & $\begin{array}{lllllllllll}28.0 & 30.4 & 33.0 & 55.5 & 57.1 & & & & & \\
28.1 & 30.4 & 31.1 & 32.7 & 35.3 & 37.7 & 46.7 & 50.7 & 56.2 & 58.6 \\
31.0 & 32.3 & 45.3 & & & & & & \end{array}$ \\
\hline Boulder. & 191.5 & 25 & $\begin{array}{llllll}28.8 & 31.6 & 41.6 & 44 & 57\end{array}$ \\
\hline La Jolla . & 241.7 & $\begin{array}{r}3 \\
25\end{array}$ & $\begin{array}{llllll}38.0 & 38.9 & 40.1 & & \\
38.4 & 39.0 & 43.4 & 65.7 & 70.0\end{array}$ \\
\hline Overton. & 257.4 & 25 & 36.8 \\
\hline Pierce Ferry. & 263.1 & $\underset{3}{35}$ & $\begin{array}{l}38.0 \pm \\
38.1 \pm 40.5 \quad 42.7 \quad 43.7 \quad 48.8 \quad 54.8 \quad 55.8 \quad 68.8 \quad 71.8\end{array}$ \\
\hline Tinemaha. & 283.5 & $\begin{array}{r}3 \\
25 \\
26\end{array}$ & $\begin{array}{l}40.7 \quad 43.7 \quad 47.0 \quad 48.7 \quad 52.2 \quad 84.4 \quad 85.7 \\
41.041 .4444 .747 .0544 .565 .081 .0 \quad 82.784 .087 .689 .9 \\
44.0 \quad 46.459 .8 \quad 82.9\end{array}$ \\
\hline Santa Barbara. & 297.1 & $\begin{array}{r}3 \\
25\end{array}$ & 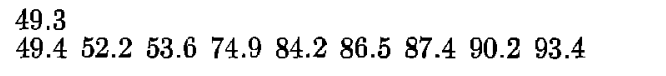 \\
\hline Tucson. & 608.5 & $\begin{array}{r}3 \\
25\end{array}$ & $\begin{array}{l}79.5 \\
79.582 .6\end{array}$ \\
\hline
\end{tabular}


TABLE 3

Orserved Trayel Times of Manix Shocks, Group a2, Including the Paincipal Earthquake, No, 1

(Serial numbers and origin times are as given in table 1 . Epicenter $34^{\circ} 59 ! 5 \mathrm{~N}, 116^{\circ} 33 ! 5 \mathrm{~W}$. $h=16 \mathrm{~km}$.)

\begin{tabular}{|c|c|c|c|}
\hline Station & $\underset{\substack{\text { Distance } \\
\text { (km.) }}}{ }$ & $\begin{array}{c}\text { Shock } \\
\text { no. }\end{array}$ & Travel times (sec.) \\
\hline Riverside. & 133.8 & $\begin{array}{r}1 \\
23 \\
34\end{array}$ & $\begin{array}{llllll}21.4 & & & & & \\
21.6 & 22.5 & 24.9 & 27.8 & 36.4 & 37.5 \\
21.1 & 21.9 & 23.4 & 36.7 & 37.6 & 40.6\end{array}$ \\
\hline Mount Wilson. & 161.6 & $\begin{array}{r}1 \\
23 \\
34\end{array}$ & 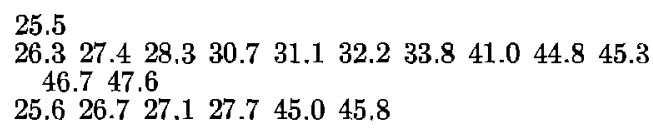 \\
\hline Pasadena. & 175.1 & $\begin{array}{r}1 \\
23 \\
34\end{array}$ & $\begin{array}{llllllll}26.8 & 28.2 & 53.3 & & & & & \\
28.9 & 29.9 & 38.7 & 44.5 & 48.9 & 51.0 & \\
26.5 & 27.8 & 28.3 & 28.7 & 45.1 & 47.4 & 48.0\end{array}$ \\
\hline Haiwee. . & 180.0 & $\begin{array}{r}1 \\
23 \\
34\end{array}$ & $\begin{array}{llllllllll}27.5 & 27.8 & 31.5 & 34.9 & & & & & & \\
27.7 & 28.8 & 29.7 & 51.4 & 53.4 & 53.8 & 55.0 & & & \\
27.6 & 28.2 & 32.7 & 34.4 & 35.8 & 46.9 & 51.5 & 53.0 & 54.0 & 54.9\end{array}$ \\
\hline Palomar. & 184.2 & $\begin{array}{r}1 \\
\mathbf{3 4}\end{array}$ & $\begin{array}{l}28.0 \\
28.229 .9\end{array}$ \\
\hline Boulder. & 191.2 & $\begin{array}{r}1 \\
23 \\
34\end{array}$ & 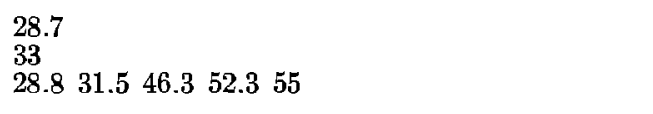 \\
\hline La Jolla. & 244.6 & $\begin{array}{l}1 \\
23 \\
34\end{array}$ & $\begin{array}{llllllll}35.6 & & & & & & & \\
38.8 & 39.5 & 40.8 & 47.8 & 65.9 & 67.4 & 68.5 & 69.0 \\
38.3 & 38.8 & 40.3 & 53.3 & 66.0 & 67.3\end{array}$ \\
\hline Overton. & 256.6 & 1 & $37.4 \pm$ \\
\hline Pierce Ferry. & 263.3 & $\begin{array}{l}1 \\
23 \\
34\end{array}$ & $\begin{array}{lllll}38.1 & & & \\
38.3 & & & & \\
38.3 & 44.3 & 53 & 67 & 73\end{array}$ \\
\hline Tinemaha... & 279.2 & $\begin{array}{l}1 \\
23 \\
34\end{array}$ & $\begin{array}{lllllllll}40.5 & 43.3 & 49.3 & & & & & & \\
40.5 & 46.1 & 47.0 & 49.3 & 63.4 & 64.3 & 80.5 & 82.0 & \\
41.3 & 42.8 & 49.3 & 50.7 & 63.2 & 67.3 & 81.8 & 82.7 & 85.5\end{array}$ \\
\hline Santa Barbara. & 295.5 & $\begin{array}{r}1 \\
23 \\
34\end{array}$ & $\begin{array}{llllllllllllllll}41.9 & 43.0 & 43.6 & 52.1 & 53.0 & & & & & & \\
51.0 & 51.9 & 53.6 & 56.6 & 77.5 & 86.6 & 87.2 & 88.4 & & & \\
48.1 & 51.2 & 51.5 & 52.1 & 53.2 & 87.0 & 88.4 & 89.4 & 90.3 & 91.8\end{array}$ \\
\hline Fresno..... & 352.6 & 1 & 50.9 \\
\hline Berkeley . & 602.9 & 1 & 80.2 \\
\hline Tucson. & 612.2 & $\begin{array}{r}1 \\
34\end{array}$ & $\begin{array}{l}81.2 \\
80.5\end{array}$ \\
\hline
\end{tabular}


TABLE 4

Observed Trayel Times of Manix Shocks, Group A3

(Serial numbers and origin times are as given in table 1. Epicenter $34^{\circ} 58^{\prime} \mathrm{N}, 116^{\circ} 33^{\prime} \mathrm{W} . h=16 \mathrm{~km}$.)

\begin{tabular}{|c|c|c|c|}
\hline Station & $\underset{(\mathrm{km} .)}{\text { Distance }}$ & $\begin{array}{l}\text { Shock } \\
\text { no. }\end{array}$ & Travel times (sec.) \\
\hline Old Woman Springs. & 63.0 & 14 & 10.3 \\
\hline Riverside... & 131.6 & $\begin{array}{r}4 \\
5 \\
14 \\
27 \\
31\end{array}$ & 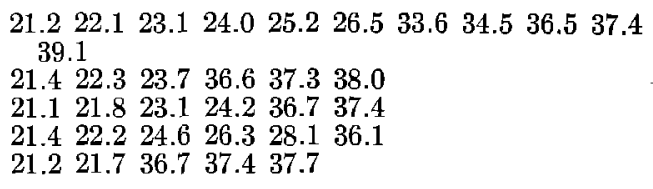 \\
\hline Mount Wilson. . & 160.9 & $\begin{array}{r}4 \\
5 \\
14 \\
27 \\
31\end{array}$ & 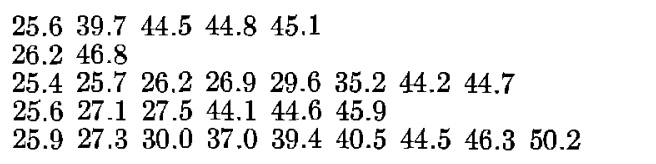 \\
\hline Pasadena. & 174.1 & $\begin{array}{r}4 \\
5 \\
14 \\
27 \\
31\end{array}$ & 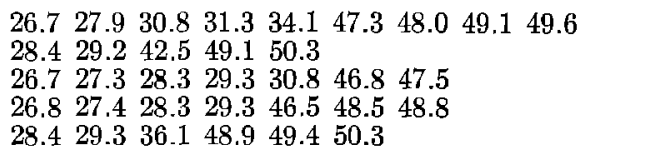 \\
\hline Palomar. & 181.6 & $\begin{array}{r}4 \\
5 \\
14 \\
27 \\
31\end{array}$ & 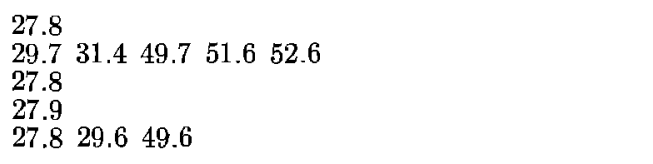 \\
\hline Haiwee. & 182.5 & $\begin{array}{r}4 \\
5 \\
14 \\
27 \\
31\end{array}$ & $\begin{array}{llllllllll}27.8 & 29.9 & 33.0 & 34.2 & 48.6 & 48.9 & 53.2 & & & \\
29.9 & 31.3 & 50.8 & 52.4 & 53.1 & & & & & \\
27.8 & 28.9 & 30.0 & 32.4 & 34.4 & 37.5 & 45.1 & 48.9 & 54.0 & \\
27.8 & 28.5 & 30.0 & 30.8 & 33.2 & 34.7 & 48.9 & 51.8 & 53.6 & 55.1 \\
27.9 & 30.4 & 33.0 & 37.5 & 50.4 & 52.8 & & & & \end{array}$ \\
\hline Boulder City. . & 192.2 & $\begin{array}{r}4 \\
14 \\
27 \\
31\end{array}$ & $\begin{array}{ll}28.0 & \\
28.7 & \\
28.8 & 32.8 \\
34.5 & 55.5\end{array}$ \\
\hline La Jolla . & 242.2 & $\begin{array}{r}4 \\
5 \\
14 \\
27\end{array}$ & 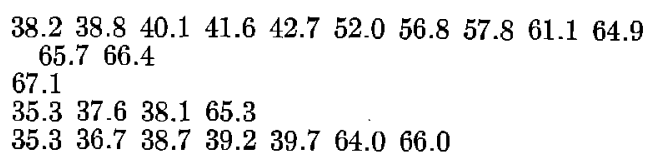 \\
\hline Overton. . & 257.9 & $\begin{array}{l}14 \\
25\end{array}$ & $\begin{array}{l}37.1 \\
36.8\end{array}$ \\
\hline Pierce Ferry. & 264.0 & $\begin{array}{r}4 \\
14 \\
27\end{array}$ & $\begin{array}{l}38.3 \pm \\
38.0 \\
38.4\end{array}$ \\
\hline
\end{tabular}


TABLE 4-Continued

\begin{tabular}{|c|c|c|c|}
\hline Station & $\underset{(\mathrm{km} .)}{\text { Distance }}$ & $\begin{array}{l}\text { Shock } \\
\text { no. }\end{array}$ & Trave] times (sec.) \\
\hline Tinemaha. & 281.9 & $\begin{array}{r}4 \\
5 \\
14 \\
27 \\
31\end{array}$ & $\begin{array}{llllllllll}40.5 & 42.5 & 44.8 & 46.6 & 79.5 & 80.6 & & & & \\
41.0 & 45.6 & 46.2 & 49.4 & 65.1 & 73.0 & 86.3 & 97.8 & & \\
40.8 & 43.3 & 46.3 & 58.9 & 60.4 & 70.3 & 82.3 & & & \\
40.6 & 46.9 & 48.6 & 52.4 & 54.1 & 60.1 & 76.8 & 78.6 & 80.7 & 82.4 \\
41.0 & 46.3 & 48.7 & 50.3 & 53.2 & 63.4 & 65.8 & 80.0 & 80.5 & \end{array}$ \\
\hline Santa Barbara. & 295.8 & $\begin{array}{r}4 \\
14 \\
27\end{array}$ & $\begin{array}{llllllllll}46.9 & 49.5 & 52.9 & 73.3 & 74.2 & 80.7 & 84.3 & 86.4 & 88.6 & \\
41.9 & 43.4 & 49.4 & 51.0 & 52.8 & 84.4 & 86.3 & & & \\
41.9 & 47.1 & 48.9 & 52.2 & 52.9 & 61.8 & 74.2 & 79.0 & 84.4 & 85.8\end{array}$ \\
\hline Tucson...... & 610.1 & $\begin{array}{r}4 \\
14 \\
27\end{array}$ & $\begin{array}{l}80.1 \\
79.9 \\
80.1\end{array}$ \\
\hline
\end{tabular}

The small dispersal in calculated $K$ shows that the two epicenters are unusually well determined; unless there is some large effect of different structures or velocities in different azimuths, they are correct to about one minute of latitude or longitude.

Table 2 gives the complete set of readings for the shocks of Group A1, Nos. $3,25,26$, and table 4 those for shocks of Group A3, Nos. 4, 5, 14, 27, 31. These are given as travel times, i.e., as elapsed times following the corresponding origin times in table 1 . The times of the later waves as well as of the first motions can be compared directly; the agreement is good.

Table 3 gives readings for Group A2, Nos. 1, 23, 34. No. 1 is the main shock. The epicenter is taken as $34^{\circ} 59^{\prime} .5 \mathrm{~N}, 116^{\circ} 33^{\prime} .5 \mathrm{~W}$, and times are calculated from $P n-O=K+\Delta / 8.2+$ height correction, using for each station the value of $K$ found for shock No. 14. The results are as follows:

Station

Riverside

Mount Wilson.

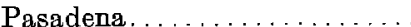

Haiwee.

Palomar. ....................

Boulder City.

La Jolla.

Overton.

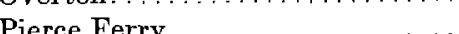

Cinemaha $\ldots \ldots \ldots \ldots \ldots \ldots$

Santa Barbara................

Berkeley..................

Tucson.

\section{$\Delta$}

133.8

161.6

175.1

180.0

184.2

191.2

244.6

256.6

263.3

279.2

295.5

602.9

612.2
K

5. 1

5. 6

5.5

5.3

5.5

5.2

5.8

5. 6

5.8

6.2

5.8

6.7

5.4

$P n-O$
21.4
25.5
26.9
27.5
28.2
28.6
35.6
36.9
37.9
40.4
41.8
80.2
80.2

21.4

25.5

26

28.6

35.6

36.9

37.9

40.4

41.8

80.2
No. 1 $P n$ obs. $\quad O$ calc

$27.0 \quad 05.6$

$31.1 \quad 05.6$

$32.4 \quad 05.5$

$33.1 \quad 05.6$

$33.6 \quad 05.4$

$34.3 \quad 05.7$

$41.2 \quad 05.6$

$43 \quad 06 \pm$

$43.7 \quad 05.8$

$46.0 \quad 05.6$

$47.5 \quad 05.7$

$85.8 \quad 05.6$

$85.6 \quad 05.4$ 
The excellent agreement extends to the late arrivals at Tinemaha and Berkeley; these indicate a delayed $\mathrm{Pn}$ ascribable to the Sierra Nevada structures. The origin time of the principal shock, No. 1, is determined as $07: 58: 05.6$, with an error not likely to exceed one-tenth second unless its depth differs materially from that of No. 14 or No. 25. The accuracy of this timing depends on the velocities used for $\mathrm{Pn}$ and $\mathrm{p}$; but it is unlikely that any future revision will materially affect the result. The epicenter $34^{\circ} 59^{\prime} .5 \mathrm{~N}, 116^{\circ} 33.5 \mathrm{~W}$, can hardly be in error by more than a minute of latitude or longitude (about $2 \mathrm{~km}$.) unless there is some large azimuthal difference in velocities or structures.

Table 5 gives readings for shocks Nos. 13 and 16, assigned to Group A4. The evidence places their epicenter close to $35^{\circ} 00^{\prime} \mathrm{N}, 116^{\circ} 34^{\prime} \mathrm{W}$, which is about a kilometer northwest of that of the principal shock (No. 1). No. 16 is the larger and better recorded. For $p$ the findings are as follows, assuming a depth of $16 \mathrm{~km}$.

\begin{tabular}{|c|c|c|c|c|}
\hline Station & $\Delta$ & $p=03: 40$ : & $p-O$ calc. & $O=03: 40$ \\
\hline Old Woman Springs. & 66.2 & 15.6 & 10.7 & 04.9 \\
\hline Riverside & 134.1 & 26.2 & 21.3 & 04.9 \\
\hline
\end{tabular}

TABLE 5

Observed Travel Times of Manix Shocks, Group A4

(Serial numbers and origin times are as given in table 1.

Epicenter $35^{\circ} 00^{\prime} \mathrm{N}, 116^{\circ} 34^{\prime} \mathrm{W} . h=16 \mathrm{~km}$.)

\begin{tabular}{|c|c|c|c|}
\hline Station & $\underset{(k \operatorname{mis} .)}{\text { Distance }}$ & $\begin{array}{c}\text { Shock } \\
\text { no. }\end{array}$ & Travel times (sec.) \\
\hline Old Woman Springs. & 66.2 & $\begin{array}{l}13 \\
16\end{array}$ & $\begin{array}{lll}10.4 & 17.3 & \\
10.8 & 17.3 & 18.4\end{array}$ \\
\hline Riverside. & 134.1 & $\begin{array}{l}13 \\
16\end{array}$ & 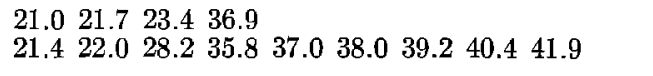 \\
\hline Mount Wilson. & 161.5 & $\begin{array}{l}13 \\
16\end{array}$ & $\begin{array}{lllllll}25.6 & 26.2 & 44.6 & 45.5 & 47.0 & & \\
25.6 & 26.1 & 28.8 & 29.4 & 30.2 & 45.0 & 46.5\end{array}$ \\
\hline Pasadena. & 175.0 & $\begin{array}{l}13 \\
16\end{array}$ & $\begin{array}{llllllll}27.1 & 27.7 & 29.0 & 31.5 & 33.6 & 46.5 & 48.1 & 50.9 \\
26.9 & 28.2 & 29.1 & 30.6 & 31.3 & 38.2 & 48.3 & 50.2\end{array}$ \\
\hline Haiwee. & 178.8 & $\begin{array}{l}13 \\
16\end{array}$ & 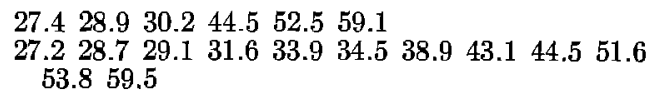 \\
\hline Palomar. & 185.0 & $\begin{array}{l}13 \\
16\end{array}$ & $\begin{array}{lllllllll}28.3 & 30.4 & 39.3 & 48.5 & 50.1 & 50.6 & & & \\
28.1 & 30.0 & 33.9 & 35.9 & 42.6 & 43.0 & 46.5 & 48.4 & 51.4\end{array}$ \\
\hline La Jolla. & 245.2 & $\begin{array}{l}13 \\
16\end{array}$ & 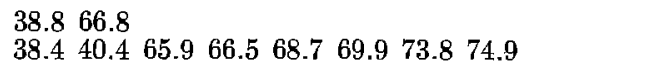 \\
\hline Tinemaha. & 278.0 & $\begin{array}{l}13 \\
16\end{array}$ & 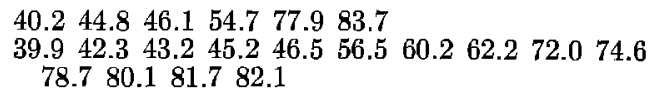 \\
\hline Santa Barbara. & 294.9 & 16 & $\begin{array}{lllll}52.5 & 55.5 & 75.5 & 80.0 & 85.4\end{array}$ \\
\hline
\end{tabular}


TABLE 6

Observed Travel Times of Manix Shocks, Group C

(Serial numbers and origin times are as given in table 1. Epicenter $34^{\circ} 57 ! 5 \mathrm{~N}, 116^{\circ} 32^{\prime} \mathrm{W} . h=10 \pm \mathrm{km}$.)

\begin{tabular}{|c|c|c|c|}
\hline Station & $\begin{array}{c}\text { Distance } \\
\text { (km.) }\end{array}$ & $\begin{array}{c}\text { Shook } \\
\text { no. }\end{array}$ & Travel times (sec.) \\
\hline Old Woman Springs. & 62.6 & $\begin{array}{r}7 \\
8 \\
9 \\
10 \\
12\end{array}$ & $\begin{array}{rr}10.2 & \\
10.0 & 17.9 \\
10.3 & \\
10.3 & 17.3 \\
9.9 & 17.7\end{array}$ \\
\hline Riverside. & 132.1 & $\begin{array}{r}7 \\
8 \\
9 \\
10 \\
12 \\
24\end{array}$ & $\begin{array}{llllllll}21.2 & 22.4 & 24.1 & 27.2 & 36.7 & 37.2 & \\
21.2 & 21.6 & 22.8 & 30.5 & 36.5 & 37.6 \\
21.5 & 23.6 & 27.3 & 36.9 & 40.2 & & \\
21.4 & 22.1 & 23.4 & 36.7 & & & \\
21.3 & 21.8 & 22.6 & 28.1 & 30.4 & 36.8 & 37.7 & 38.5 \\
21.4 & 22.1 & 23.1 & 33.7 & 34.7 & 37.4 & 38.9\end{array}$ \\
\hline Mount Wilson. & 161.7 & $\begin{array}{r}7 \\
8 \\
9 \\
10 \\
12 \\
24\end{array}$ & $\begin{array}{llllllllll}26.2 & 26.6 & 27.8 & 29.7 & 44.9 & 45.4 & & & & \\
26.1 & 27.1 & 28.3 & 29.1 & 33.9 & 40.1 & 44.8 & 45.3 & 45.7 & 47.0 \\
48.1 & & & & & & & & & \\
26.0 & 27.1 & 30.1 & 45.7 & 46.0 & 48.1 & 48.6 & & \\
26.4 & 27.2 & 28.6 & 29.8 & 32.6 & 45.2 & 46.5 & & \\
26.3 & 28.4 & 37.8 & & & & & & & \\
26.4 & 26.9 & 28.8 & 34.8 & 37.9 & 45.0 & 45.3 & 46.3\end{array}$ \\
\hline Pasadena. & 175.2 & $\begin{array}{r}7 \\
8 \\
9 \\
10 \\
12 \\
24\end{array}$ & 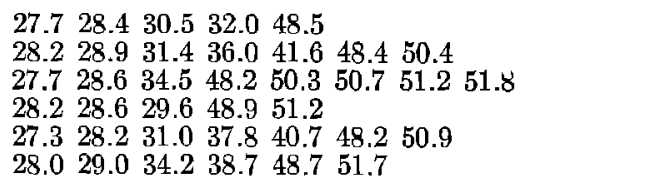 \\
\hline Palomar. & 180.9 & $\begin{array}{r}7 \\
8 \\
9 \\
10 \\
12 \\
24\end{array}$ & 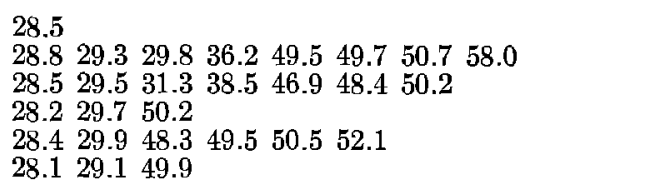 \\
\hline Haiwee. . & 184.2 & $\begin{array}{r}7 \\
8 \\
9 \\
10 \\
12 \\
24\end{array}$ & $\begin{array}{rrrrrrrrrrr}29.0 & 31.0 & 32.6 & 38.0 & 40.9 & 46.4 & 52.2 & & & \\
31.0 & 32.3 & 35.3 & 46.6 & 53.2 & 56.8 & 57.7 & & & \\
29.1 & 31.1 & 33.7 & 35.3 & 44.3 & 46.8 & 50.8 & 52.8 & 55.6 & 57.8 \\
28.9 & 30.9 & 38.8 & 40.6 & 47.5 & & & & & \\
29.0 & 31.0 & 32.6 & 34.1 & 35.7 & 39.8 & 42.3 & 44.8 & 46.4 & 49.6 \\
50.8 & 53.6 & 56.7 & 63.4 & & & & & \\
29.1 & 30.5 & 31.2 & 32.6 & 34.3 & 45.4 & 53.5 & 54.3 & & \end{array}$ \\
\hline Boulder. & 191.5 & $\begin{array}{r}7 \\
9 \\
12 \\
24\end{array}$ & $\begin{array}{lll}29.7 & & \\
32.3 & & \\
33.0 & & \\
29.9 & 32.3 & 58.9\end{array}$ \\
\hline La Jolla. & 241.7 & $\begin{array}{r}7 \\
12 \\
24\end{array}$ & $\begin{array}{llllllll}37.2 & 38.0 & 39.0 & 66.4 & & & \\
38.7 & 40.1 & 64.9 & 66.0 & 67.7 & & \\
38.4 & 40.8 & 65.5 & 67.8 & 68.3 & 69.4 & 70.9\end{array}$ \\
\hline
\end{tabular}


TABLE 6-Continued

\begin{tabular}{|c|c|c|c|}
\hline Station & $\begin{array}{c}\text { Distance } \\
(\mathrm{km} .)\end{array}$ & $\begin{array}{l}\text { Shock } \\
\text { no. }\end{array}$ & Travel times (sec.) \\
\hline Pierce Ferry. . & 263.1 & $\begin{array}{r}7 \\
9 \\
12 \\
24\end{array}$ & $\begin{array}{lllllll} & 38 \\
39 & & & & & & \\
39.3 & & & & & & \\
38.8 & 41.2 & 45 & 56 & 70 & 76\end{array}$ \\
\hline Tinemaha......... & 283.5 & $\begin{array}{r}7 \\
8 \\
9 \\
10 \\
12 \\
24\end{array}$ & 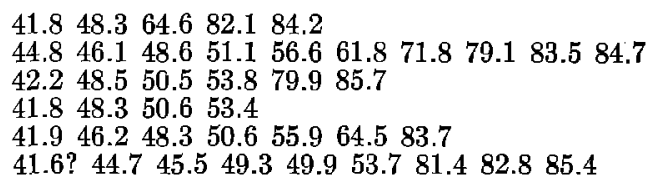 \\
\hline Santa Barbara..... & 297.1 & $\begin{array}{r}7 \\
10\end{array}$ & $\begin{array}{l}43.7 ? \quad 48.5 \quad 50.987 .3 \quad 88.3 \quad 89.9 \\
89.3\end{array}$ \\
\hline Tucson. & 608.5 & $\begin{array}{r}7 \\
8 \\
9 \\
12 \\
24\end{array}$ & $\begin{array}{l}81.0 \\
80.782 .6 \\
82.2 \\
80.8 \\
79.6\end{array}$ \\
\hline
\end{tabular}

For $P n$, using the values of $K$ found for No. 14 and applying the same height corrections, we find:

\begin{tabular}{|c|c|c|c|c|}
\hline Station & $\Delta$ & $P n=03 ; 40:$ & $\Delta / 8.2$ & $O=03: 40$ \\
\hline Mount Wilson. & 161.5 & 30.4 & 19.7 & 04.9 \\
\hline Pasadena.... & $175: 0$ & 31.7 & 21.3 & 04.9 \\
\hline Haiwee. . & 178.8 & 32.0 & 21.8 & 04.7 \\
\hline Palomar. & 185.0 & 32.9 & 22.6 & 04.6 \\
\hline Tinemaha.. & 278.0 & 44.7 & 33.9 & 04.4 \\
\hline
\end{tabular}

The origin time has been taken as $03: 40: 04.8$, as given in table 1 and used in table 5 .

No. 16 is notable for very short periods in Pn at Haiwee, Palomar, and Tinemaha, and for $\mathbf{S}$ amplitudes that are unusually small às compared to those of P. No. 13 appears to have the same character. This suggests origination in displacements of unusually short duration and small extent.

Table 6 presents travel times for the six shocks of Group C. The largest and best recorded is No. 7. The arrival of the first motion 0.5 sec. earlier at Palomar than at Haiwee suggests assigning these shocks to the same epicenter as Group $\mathrm{A} 1,34^{\circ} 57^{\prime} .5 \mathrm{~N}, 116^{\circ} 32^{\prime} \mathrm{W}$. The result of subtracting the travel times of No. 25 from the first motions of No. 7 is as follows: 


\begin{tabular}{|c|c|c|c|c|}
\hline Station & 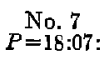 & $\begin{array}{l}\text { No. } 25 \\
P-O\end{array}$ & $\begin{array}{c}\text { No. } 7 \\
O=18: 07:\end{array}$ & $O=18: 07: 11.5$ \\
\hline Old Woman Springs... & 21.7 & 10.2 & 11.5 & .. \\
\hline Riverside............... & 32.7 & 21.2 & 11.5 & 5.1 \\
\hline Mount Wilson. . . . . . . . . . . . . & 37.7 & 25.5 & 12.2 & 6.2 \\
\hline Pasadena. & 39.2 & 26.8 & 12.4 & 6.3 \\
\hline Palomar................ & 40.0 & 27.6 & 12.4 & 6.2 \\
\hline Haiwee................. & 40.5 & 28.1 & 12.4 & 6.3 \\
\hline Boulder City . . . . . . . . . . . . & 41.2 & 28.8 & 12.4 & 6.2 \\
\hline Pierce Ferry . . . . . . . . . . & 50 & 38 & 12 & $6.4 \pm$ \\
\hline Tinemaha . . . . . . . . . . . . & 53.3 & 41.0 & 12.3 & 7.0 \\
\hline Tueson................. & 92.5 & 79.5 & 13.0 & 6.7 \\
\hline
\end{tabular}

For the stations where the first motion is probably $\mathrm{Pn}$, the origin time is indicated to be close to 18:07:12.4; whereas Riverside and Old Woman Springs, which presumably have recorded $p$, indicate an origin time 0.9 seconds earlier. This cannot be obviated by changing the assumed epicenter. The only ready explanation is to suppose a shallower hypocenter for No. 7 than for No. 25. With a mean velocity of $6.34 \mathrm{~km} / \mathrm{sec}$. above the deeper hypocenter, and a velocity of $8.2 \mathrm{~km} / \mathrm{sec}$. for $\mathrm{Pn}$, the travel time for the latter phase should increase about 0.1 sec. for a decrease in depth of one $\mathrm{km}$. The depth of origin of shock No. 7 may then be estimated at about $7 \mathrm{~km}$., supposing that of No. 25 to be $16 \mathrm{~km}$.

Table 7 gives times for the shocks of Group B, which are assigned to an epicenter at $34^{\circ} 56^{\prime} \mathrm{N}, 116^{\circ} 31^{\prime} \mathrm{W}$. The largest of these recorded at Old Woman Springs is No. 11. The large, clear beginning of this record is at 19:32:19.8. There is a smaller sharp impulse involved in background disturbance 0.9 sec. earlier; this has been included in the tabulation, although apparently it is an accidental disturbance or a result of an earlier smaller shock. Unsuccessful attempts have been made to explain it as a refracted wave arriving before the direct $p$. No similar arrival has been noted for any of the other shocks of the group. The distance is $60.3 \mathrm{~km}$; f for a depth of $16 \mathrm{~km}$. this gives $p-O=9.8$ sec., whence $O=19: 32: 10.0$ (using the time of the large clear impulse).

For Riverside the time of first motion is 19:32:31.1; the distance being 130.4 $\mathrm{km}$., a 16-km. depth would require $p-O=20.7 \mathrm{sec}$., or $O=19: 32: 10.4$. For Riverside and the other stations, calculation of $\mathrm{Pn}$ times and comparison with No. 7 gives the following results for No. 11:

\begin{tabular}{|c|c|c|c|c|c|}
\hline Station & $\Delta$ & $P=19: 32:$ & $\Delta / 8.2$ & $\begin{array}{c}P-\Delta / 8.2 \\
19: 32:\end{array}$ & $\begin{array}{l}O \text { calc. } \\
19: 32:\end{array}$ \\
\hline Riverside. & 130.4 & 31.1 & 15.9 & 15.2 & 10.1 \\
\hline Mount Wilson......... & 161.7 & 36.3 & 19.7 & 16.6 & 10.2 \\
\hline Pasadena. . . . . . . . & 175.1 & 37.4 & 21.4 & 16.0 & 9.7 \\
\hline Palomar............ & 178.5 & 38.2 & 21.8 & 16.4 & 10.0 \\
\hline Haiwee. . . . . . . . . . & 187.3 & 39.4 & 22.8 & 16.6 & 10.1 \\
\hline Boulder City . . . . . . . & 192.0 & 39.7 & 23.4 & 16.3 & 10.0 \\
\hline Overton............ & 258.2 & 48 & 31,5 & $16.5 \pm$ & $\ldots$ \\
\hline Pierce Ferry . . . . . . . . . & 263.3 & 49 & 32.1 & $16.9 \pm$ & \\
\hline Tinemaha. .......... & 286.7 & 52.2 & 35.0 & 17.2 & 10.0 \\
\hline Tueson.... & 605.8 & 90.2 & 73.9 & 16.3 & 9.5 \\
\hline
\end{tabular}




\section{TABLE 7}

Observed Thayel Times of Manix Shocks, Group B

(Serial numbers and origin times are as given in table 1. Epicenter $34^{\circ} 56^{\prime} \mathrm{N}, 116^{\circ} 31^{\prime} \mathrm{W} . h=10 \pm \mathrm{km}$.)

\begin{tabular}{|c|c|c|c|}
\hline Station & $\underset{(\mathrm{km} .)}{\text { Distance }}$ & $\begin{array}{c}\text { Shoek } \\
\text { no. }\end{array}$ & Travel times (sec.) \\
\hline Old Woman Springs. & 60.3 & $\begin{array}{l}11 \\
15 \\
17 \\
18\end{array}$ & $\begin{array}{ll}08.9 ? & 09.8 \\
09.9 & \\
09.6 & 11.9 \\
09.8 & \end{array}$ \\
\hline Riverside. . & 130.4 & $\begin{array}{r}2 \\
6 \\
11 \\
15 \\
17 \\
18 \\
19 \\
20 \\
21 \\
22 \\
28 \\
29 \\
30 \\
32 \\
33\end{array}$ & 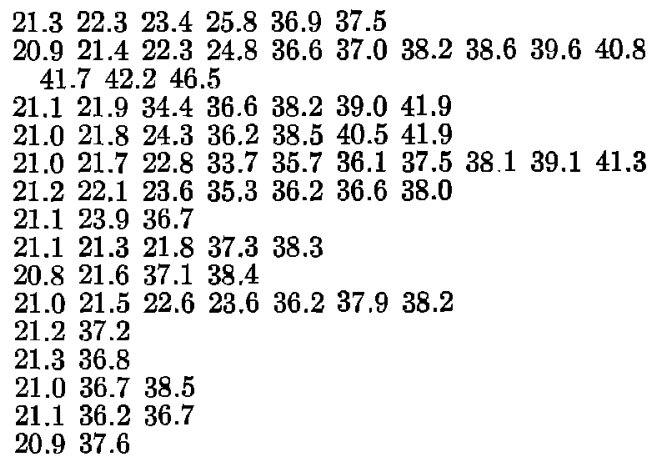 \\
\hline Mount Wilson. . & 161.7 & $\begin{array}{r}2 \\
6 \\
11 \\
15 \\
17 \\
18 \\
19 \\
20 \\
21 \\
22 \\
28 \\
29 \\
30 \\
32 \\
33\end{array}$ & 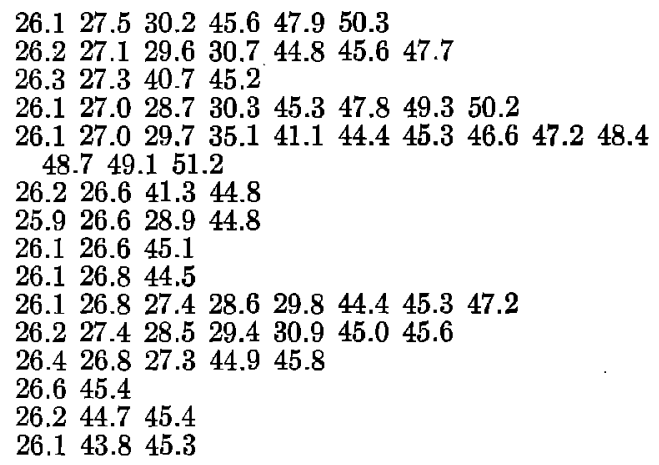 \\
\hline Pasadena. & 175.1 & $\begin{array}{r}2 \\
6 \\
11 \\
15 \\
17 \\
18 \\
19 \\
20 \\
21 \\
22 \\
28 \\
29 \\
30 \\
32 \\
33\end{array}$ & 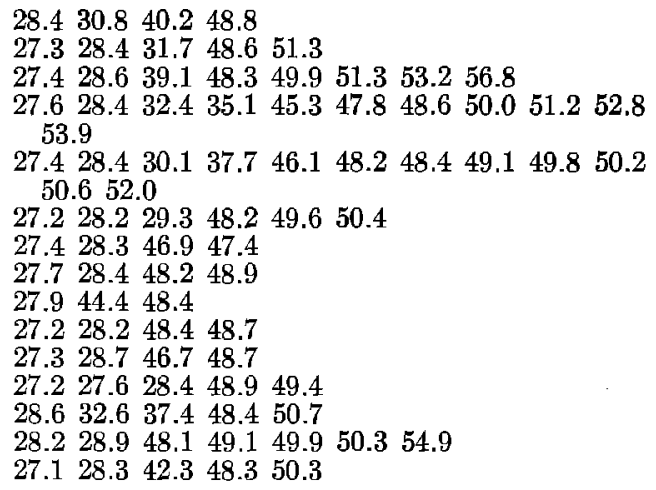 \\
\hline
\end{tabular}


TABLE 7-Continued

\begin{tabular}{|c|c|c|c|}
\hline Station & $\begin{array}{c}\text { Distance } \\
(\mathrm{kmm} .)\end{array}$ & $\begin{array}{l}\text { Shooks } \\
\text { no. }\end{array}$ & Travel times (sec.) \\
\hline Palomar. . & 178.5 & $\begin{array}{r}6 \\
11 \\
15 \\
17 \\
18 \\
19 \\
28 \\
29 \\
30 \\
32 \\
38\end{array}$ & 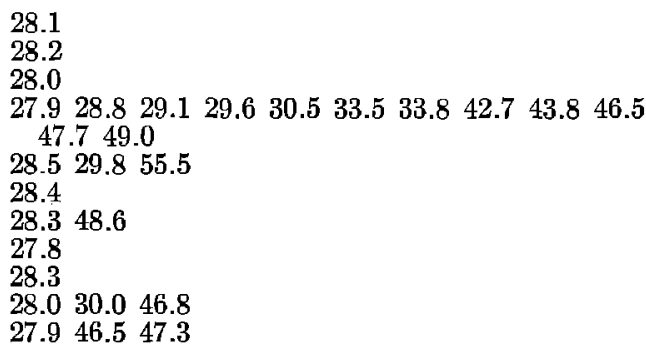 \\
\hline Haiwee. & 187.3 & $\begin{array}{r}2 \\
6 \\
11 \\
15 \\
17 \\
18 \\
19 \\
20 \\
21 \\
22 \\
28 \\
29 \\
30 \\
32 \\
33\end{array}$ & 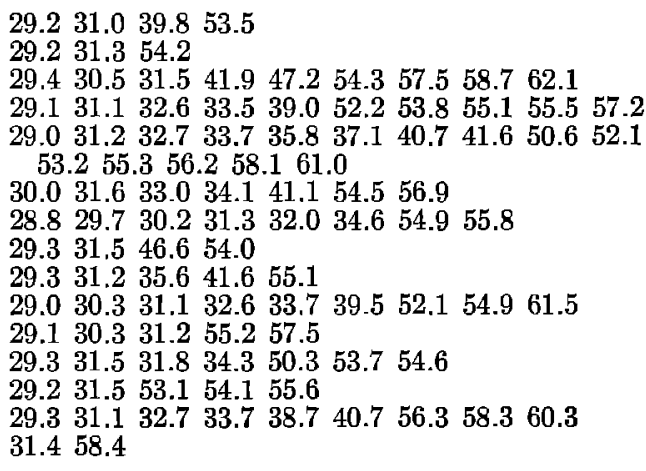 \\
\hline Boulder. . & 192.0 & $\begin{array}{r}2 \\
6 \\
11 \\
15 \\
18 \\
19 \\
20 \\
21 \\
22 \\
28 \\
29 \\
30 \\
32 \\
33\end{array}$ & $\begin{array}{l}27.9 \\
30.4 \\
29.7 \\
29.6 \\
27 \\
29.532 .3 \\
29.734 .7 \\
29.933 .1 \\
32.6 \pm 52.6 \pm \\
30.033 .033 .753 \\
(24.6 \pm) 29.6 \pm 56.6 \pm \\
3256.3 \\
29.533 .6 \quad 57.3 \\
30.133 .256 .6\end{array}$ \\
\hline La Jolla. & 239.5 & $\begin{array}{r}2 \\
6 \\
11 \\
15 \\
17 \\
19 \\
20 \\
21 \\
22 \\
28 \\
29 \\
30 \\
32 \\
33\end{array}$ & 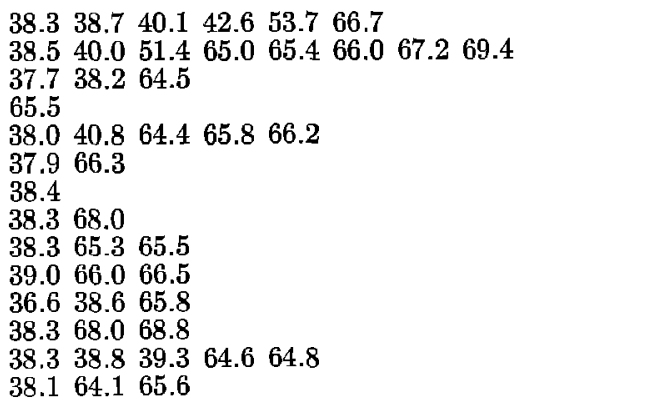 \\
\hline
\end{tabular}


TABLE 7-Continued

\begin{tabular}{|c|c|c|c|}
\hline Station & $\underset{(\mathrm{km} .)}{\operatorname{Distance}}$ & $\begin{array}{c}\text { Shook } \\
\text { no. }\end{array}$ & Travel times (sec.) \\
\hline Overton. & 258.2 & $\begin{array}{l}11 \\
15 \\
32 \\
33\end{array}$ & $\begin{array}{l}38.0 \pm \\
38 \\
39.144 .7 \pm 51.7 \pm 55.2 \\
38.340445570 .675\end{array}$ \\
\hline Pierce Ferry... & 263.2 & $\begin{array}{l}2 \\
6 \\
11 \\
15 \\
17 \\
18 \\
19 \\
20 \\
21 \\
22 \\
28 \\
29 \\
30 \\
32 \\
33\end{array}$ & $\begin{array}{l}29 \\
39 \\
39.0 \pm \\
38.9 \\
39 \\
39 \\
39 \\
39 \\
39.043 .9 \pm \\
39.1 \\
39 \\
38.8 \quad \\
39.345 .2 \quad 54.8 \pm 68.8 \pm \\
39.245 .0 \\
3945 \quad 53.6 \quad 68.672\end{array}$ \\
\hline Tinemaha. & 286.7 & $\begin{array}{r}2 \\
6 \\
11 \\
15 \\
17 \\
18 \\
19 \\
20 \\
21 \\
22 \\
28 \\
29 \\
30 \\
32 \\
33\end{array}$ & 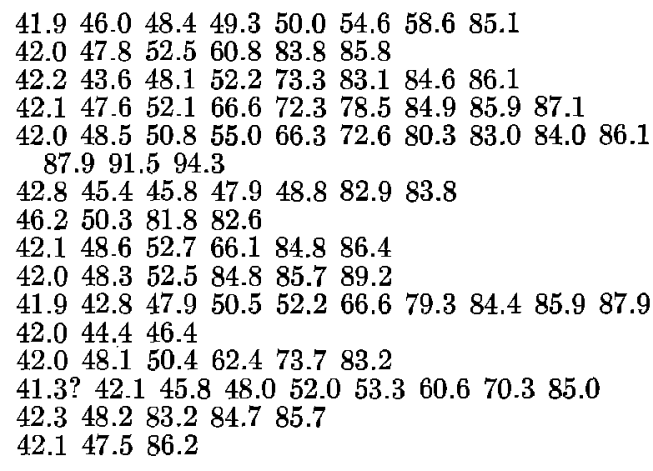 \\
\hline Santa Barbara. & 297.9 & $\begin{array}{r}2 \\
6 \\
11 \\
15 \\
17 \\
18 \\
19 \\
20 \\
21 \\
22 \\
28 \\
29 \\
30 \\
33\end{array}$ & 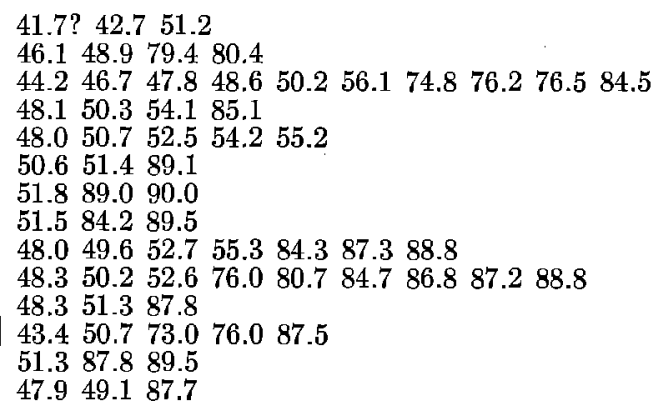 \\
\hline
\end{tabular}


TABLE 7-Concluded

\begin{tabular}{|c|c|c|c|}
\hline Station & $\begin{array}{c}\text { Distance } \\
(\mathbf{k m .})\end{array}$ & $\begin{array}{c}\text { Shook } \\
\text { no. }\end{array}$ & Travel times (sec.) \\
\hline Tucson. ..... & 605.8 & $\begin{array}{r}2 \\
6 \\
11 \\
15 \\
19 \\
20 \\
21 \\
22 \\
28 \\
29 \\
30 \\
32 \\
33\end{array}$ & $\begin{array}{lll}80.2 & & \\
80.3 & 111.0 & 176.8 \\
80.2 & & \\
80.5 & & \\
8.0 & & \\
80.5 & & \\
80.2 & 173.6 & \\
81.1 & & \\
80.5 & & \\
80.1 & \\
80.3 & & \\
80.7 & & \\
80.1 & 108 & \end{array}$ \\
\hline
\end{tabular}

It is clear that $K=5.4$ would result in an origin time from the distant stations distinctly later than that from Old Woman Springs. Direct comparison with No. 7 is effected by decreasing $P-\Delta / 8.2$ by the height correction, and then subtracting the value of $\mathrm{K}$ found for No. 7. The results are in the column headed " $O$ calc." The agreement is very good for an origin time about 19:32: 10.0, with a hypocentral depth about the same as for No. 7. The agreement with Tucson can be improved, if we suppose that the first motion measured there for No. 7 is late; if instead of the apparent origin time, 13.0, from this measurement we take that, 12.4, suggested by the other stations, we find $K=6.1$ instead of 6.7 ; and if this is applied to No. 11 the calculated origin time changes from 19:32:09.5 to 19:32:10.1. The early reading at Pasadena is not explained.

Tables 2 to 7 show that within each of the six groups the data of the several shocks are in good mutual agreement. For the smaller members of each group the first motion is often not legible at the more distant stations; on the other hand, these shocks present legible later phases which cannot be read from the often photographically underexposed seismograms of the larger shocks.

\section{Later Longitudinal Waves}

On the present interpretation, the actual first motion is either $\mathrm{p}$ or Pn, although its amplitude on the seismogram may be too small for identification. Later arrivals are often large and sharp; the tables show that some of them are very consistently recorded.

The preceding discussion has indicated that at Riverside $\mathrm{p}$ should be followed by Pn. For Group A the interval should be 0.3 sec. Only a few of the tabulated readings show this interval, but a large phase arriving at about the proper time appears on many of the seismograms. For the $\mathrm{B}$ and $\mathrm{C}$ shocks the 
evident interval is longer; it should correspond to the 0.9 sec. found in discussing No. 7. Tables 5 and 6 show such intervals ranging from 0.5 to 1.1 sec.

Gutenberg's study of 1944 identified conspicuously recorded waves the times of which were given by $P m-O=4.4+0.1440 \Delta$ and $P y-O=1.2+$ $0.1654 \Delta$. Since the 1951 change in the constant term $K$ of the equation for $\mathrm{Pn}$ from 6.2 to 5.1 makes the origin time 1.1 sec. later, the same observations would now be represented by $P m-O=3.3+0.1440 \Delta$ and $P y-O=0.1+$ $0.1654 \Delta$. Noting that the constant term for Py is now practically zero, Gutenberg concludes that this is actually the direct wave, in continuation of $\mathrm{p}$, the lower apparent velocity arising from the change in velocity with depth. He has revised the entire determination, and now (April, 1950) gives:

$$
\begin{aligned}
& P m-O=3.5+0.1427 \Delta \\
& c-O=0.2+0.1608 \Delta \\
& P y-O=1.2+0.1610 \Delta
\end{aligned}
$$

Here $c$ is the beginning of the Py group; the wave called Py, 1.0 sec. later, is the impulsive maximum of the same group.

These represent an average for southern California, and are correlated with $K=\mathbf{5} .1$ for Pn. Since for the A group we have $K=\mathbf{5 . 4}$ and for the B and C groups $K=6.3$, we may expect a corresponding increase in $P m-O$. If $\mathrm{Py}$ is actually a direct wave, it may not be similarly affected.

On seismograms of the Manix series these waves are often large, and may be the first measurable motion for the smaller shocks. At Haiwee the large second phase is regularly close to 2.0 sec. after $\mathrm{Pn}$; the distance ranges from 180 to $187 \mathrm{~km}$. At Palomar, in the same range of distance, a similar phase is recorded, but is often earlier, down to 1.5 sec. after Pn.

At Haiwee, for the A3 epicenter, distant $182.5 \mathrm{~km}$., the travel time of the large phase is 29.9 sec. Supposing it to be $\mathrm{Pm}$, we calculate $29.9-0.1427 \Delta=$ 4.0. If $\mathrm{Pm}$ is a refracted wave, this should be decreased to 3.9 to correct for the elevation of Haiwee. Since we have $K=5.4$ in place of $K=5.1$ used by Gutenberg, 3.9 for $P m$ corresponds to 3.6 , in good agreement with his results. However, the readings will also fit Gutenberg's $c$; for $29.9-0.1608 \Delta=0.5$. The readings at Palomar would then give a nearly zero constant term, which would suit a direct wave. Whether it is $\mathrm{Pm}$ or not, the phase at Haiwee should be a refracted wave and not a direct wave, since the interval after $\mathrm{Pn}$ is the same for Group A as for the shallower shocks of Groups B and C.

At Tinemaha the first motion is followed after about 5 seconds by a large phase or succession of phases, which does not begin sharply. Mean travel times $t$, and resulting calculations, are the following. 


\begin{tabular}{|c|c|c|c|c|}
\hline Group & $\Delta$ & $t$ & $t-0.1610 \Delta$ & $t-0.1427 \Delta$ \\
\hline A1. & 283.5 & 46.9 & 01.3 & 06.4 \\
\hline A2. & 279.2 & 46.1 & 01.1 & 06.3 \\
\hline A3. & 281.9 & 46.4 & 01.0 & 06.2 \\
\hline A4. & 278.0 & 46.3 & 01.5 & 06.7 \\
\hline C... & 283.5 & 48.4 & 02.8 & 07.9 \\
\hline$\ldots \ldots$ & 286.7 & 48.5 & 02.3 & 07.6 \\
\hline
\end{tabular}

The last column gives the results of attempting to identify these phases as Pm; they are clearly several seconds too late, if the identification at Haiwee is right. The preceding column shows that the identification as Py is satisfactory for the A group. The late arrival for the B and $\mathrm{C}$ groups must be explained by refraction, or by a lower mean velocity along a shallower path; or these waves may represent $\overline{\mathrm{P}}$.

$\mathrm{Pm}$ is represented in the Boulder City readings, arriving 2.4 to 3.1 sec. after Pn. The travel times $t$, and calculations for the constant term in Pm, are:

\begin{tabular}{|c|c|c|c|c|}
\hline Group & $\Delta$ & Shock & $t$ & $t-0.1427 \Delta$ \\
\hline A1. & 191.5 & 25 & 31.6 & 4.3 \\
\hline $\mathrm{A} 2$. & 191.2 & 34 & 31.5 & 4.2 \\
\hline C. & 191.5 & 24 & 32.3 & 5.0 \\
\hline \multirow[t]{4}{*}{ B. . } & 192.0 & 19 & 32.3 & 4.9 \\
\hline & & 21 & 33.1 & 5.7 \\
\hline & & 28 & 33.0 & 5.6 \\
\hline & & 33 & 33.2 & 5.8 \\
\hline
\end{tabular}

The results in the last column should probably be diminished slightly to allow for the elevation of Boulder City. Those for the two A group shocks agree reasonably with the results derived from the Haiwee times. Those for shocks Nos. 24 and 19 are later by approximately the difference of 0.9 sec. in the values of $K$; in other words, the interval $\mathrm{Pm}-\mathrm{Pn}$ is approximately constant, as at Haiwee. The remaining three shocks show a later arrival, possibly the same as Gutenberg's b of the 1951 revision, which follows 1.2 sec. after Pm.

At La Jolla, Pn is recorded only for the larger shocks, and the seismogram usually begins with Pm. The travel time of the first wave is then close to 38.3 sec., although there is a well-documented later arrival at about $38.8 \mathrm{sec}$. An example is shock No. 34, Group A2, distance $244.6 \mathrm{~km}$. We find $38.3-244.6 \times$ $0.1427=3.4$. For the B shocks, $38.3-239.5 \times 0.1427=4.1$.

At Santa Barbara, conspicuous late phases have times of about 47.0 and 49.4 sec. for the A shocks, 48.1 and 50.2 sec. for the B shocks. We find $47.0-$ $296 \times 0.1427=4.8$, and $49.4-296 \times 0.1610=01.7$. For the B shocks the results are $48.1-298 \times 0.1427=5.6$ and $50.2-298 \times 0.1610=2.2$. Identifications as $\mathrm{Pm}$ and $\mathrm{Py}$ are acceptable, considering the difficulty of reading such times at this station, which has a relatively high level of background disturbance. 
$\overline{\mathrm{P}}$ is recorded convincingly only at Tinemaha and Santa Barbara, although at other stations there are sporadic readings which might fit. Calculating $\bar{P}-O=-1.2+0.1799 \Delta$, the results are as follows:

\begin{tabular}{|c|c|c|c|c|c|c|}
\hline \multirow{3}{*}{ Group } & \multicolumn{3}{|c|}{ Trnemaaea } & \multicolumn{3}{|c|}{$S_{A N T A} B_{A R B A R A}$} \\
\hline & $\Delta$ & $t$ (mean) & $\bar{P}-O$ (calc.) & $\Delta$ & $t$ (mean & $-O$ (calo.) \\
\hline & 279.2 & 49.3 & 49.0 & 295.5 & 51.1 & 51.0 \\
\hline A3. & 281.9 & 48.7 & 49.5 & 295.8 & 51.0 & 51.0 \\
\hline A1. & 283.5 & 48.7 & 49.8 & 297.1 & 52.2 & 52.2 \\
\hline C. & 283.5 & 48.6 & 49.8 & 297.1 & . & 52.2 \\
\hline B. & 286.7 & 50.4 & 50.4 & 297.9 & 52.6 & 52.4 \\
\hline
\end{tabular}

The early readings at Tinemaha for Groups A1 and C may be accounted for by late waves of the Py complex. There are some similar readings for Group $\mathrm{C}$ at Santa Barbara. Note that the observed times agree with the calculations quite as well for Group B as for Group A, without regard to the probable difference in depth of origin; this is consistent with the hypothesis that $\bar{P}$ is a surface or channel wave, which should have a travel time independent of that depth.

Travel-time lines on the accompanying figures are drawn as follows:

For Group $A, p=0.1578 D$, where $D^{2}=\Delta^{2}+256 ; P n=5.4+0.12195 \Delta$, $P m=3.9+0.1427 \Delta, P y=1.2+0.1610 \Delta, \bar{P}=-1.2+0.1799 \Delta$.

For Groups B and C, $p=0.1578 \mathrm{D}$, where $D^{2}=\Delta^{2}+100 ; P n=6.0+$ $0.12195 \Delta, P m=4.5+0.1427 \Delta, P y=2.2+0.1610 \Delta, \bar{P}=-1.2+0.1799 \Delta$. The latter values of the constant terms of $\mathrm{Pn}$ and $\mathrm{Pm}$ are about $0.3 \mathrm{sec}$. less than those inferred from the larger shocks of the B and C groups (chielly No. 7). Many of the better-recorded smaller shocks (especially in the B group) show arrivals which are best represented by these earlier times. There may be variation in depth among the B group, or even in the C group; or there may be a slightly different epicenter and a missing of the first motion at some stations. Certainly the early arrivals at Pasadena are not due to measuring error; they are numerous and consistent. Accordingly, we postulate for the B group a depth of about $10 \mathrm{~km}$., corresponding to a travel time of Pn 0.6 sec. greater than for the A group.

Particular attention is directed to the readings for No. 17, which are very clearly recorded without unmanageably large amplitudes. The seismograms have been read in full detail, and the points representing this shock have been distinguished from those of others on the figures. Note especially the sharp phase arriving after 66.3 seconds at Tinemaha. This is characteristic of the $B$ shocks; it is 6 seconds earlier than $\mathrm{Sn}$.

\section{Transverse Waves}

Most of the expected waves of the $\mathbf{S}$ group are recorded. At Cave Mountain, Old Woman Springs, and Riverside, the first $\mathrm{S}$ wave should be s, the counterpart of $\mathrm{p}$. This should be verifiable in the form $p-O=1.37(s-p)$. 
The Cave Mountain seismogram shows the large shock No. 25 and a series of smaller ones, of which No. 26 is the only one legibly recorded at the more distant stations. The interval $s-p$ for No. 26 appears to be 2.3 sec., and similar intervals are recorded for the smaller shocks. There is a possibility of an $s-p$ of 2.4 sec. for No. 25 ; but the larger amplitude of the record makes this reading difficult. Now $2.3 \times 1.37=3.2$, while $p-O$ has been taken to be more than one second longer. Since No. 26 is very imperfectly recorded, it may be that its epicenter is actually nearer Cave Mountain, or that it originated near the surface. It is not likely that the data for No. 25 can be reinterpreted to fit an $s-p$ at Cave Mountain of 2.3 or 2.4. Another explanation is suggested by the later reading for No. 26, 3.5 sec. after p. Since $3.5 \times 1.37=4.8$, there would be no serious discrepancy in taking this to be s. The preceding larger impulse would remain not accounted for.

At Old Woman Springs, $\mathrm{s}$ is measurable for the smaller shocks. The results from tables 2 to 7 may be set forth as follows:

$\begin{array}{ccccc}\text { Group } & \text { Shock } & p-o & s-p & 1.37(s-p) \\ \text { A4 } \ldots \ldots \ldots \ldots \ldots \ldots & 13 & 10.4 & 7.9 & 10.8 \\ \mathrm{~A} 4 \ldots \ldots \ldots \ldots \ldots \ldots \ldots & 16 & 10.8 & 7.6 & 10.4 \\ \mathrm{C} \ldots \ldots \ldots \ldots \ldots \ldots \ldots & 8 & 10.0 & 7.9 & 10.8 \\ \mathrm{C} \ldots \ldots \ldots \ldots \ldots \ldots \ldots & 10 & 10.3 & 7.0 & 9.6 \\ \mathrm{C} \ldots \ldots \ldots \ldots \ldots \ldots & 12 & 10.0 & 7.7 & 10.5\end{array}$

The agreement is good, considering that the readings of $s$ have not been used at any point in establishing epicenters and origin times. The early $\mathrm{s}$ in No. 10 is puzzling; the measurement is very definite, and the phase is large and sharp (the recording line disappears). There is an even earlier reading for No. 16.

Data for Riverside are plentiful. The following tabulations result from selecting the shocks of magnitude 4.0 or greater; these generally have a very clear iS measurable on the torsion horizontal-component records.

\begin{tabular}{|c|c|c|c|c|}
\hline Group & Shock & $p-0$ & $s-p$ & $1.37(s-p)$ \\
\hline $\mathrm{A} 1 \ldots \ldots \ldots \ldots$ & 3 & 21.0 & 14.8 & 20.3 \\
\hline$\ldots \ldots \ldots \ldots$ & 25 & 21.2 & 14.7 & 20.1 \\
\hline A2. & 34 & 21.1 & 15.6 & 21.4 \\
\hline$\ldots \ldots \ldots \ldots$, & 4 & 21.2 & 15.3 & 21.0 \\
\hline A3. & 14 & 21.1 & 15.6 & 21.4 \\
\hline A3. & 27 & 21.4 & 14.7 & 20.1 \\
\hline$\ldots \ldots \ldots \ldots$ & 7 & 21.2 & 15.5 & 21.2 \\
\hline B. & 2 & 21.3 & 15.6 & 21.4 \\
\hline B. & 6 & 20.9 & 15.7 & 21.5 \\
\hline$\ldots \ldots \ldots$ & 11 & 21.1 & 15.5 & 21.2 \\
\hline$\ldots \ldots \ldots$ & 19 & 21.1 & 15.6 & 21.4 \\
\hline B. & 20 & 21.1 & 16.2 & 22.2 \\
\hline$\therefore \ldots$ & 21 & 20.8 & 16.3 & 22.3 \\
\hline B & 29 & 21.3 & 15.5 & 21.2 \\
\hline B. & 33 & 20.9 & 16.7 & 22.9 \\
\hline
\end{tabular}


Considering the normal irregularities in the reading of an $\mathrm{S}$ phase, these adequately confirm the identification of $\mathrm{s}$. The shocks of smaller magnitude give practically the same information.

Gutenberg now finds $S n-O=8.4+0.220 \Delta$. The corresponding phase is well recorded for the Manix shocks, particularly at Mount Wilson, where twenty-four of the thirty-four shocks show clear phases with a travel time near 45 sec. There are two such phases about a half second apart; in four instances both have been read. On subtracting $0.220 \Delta$ from the times, we find in the mean for the A group 8.9 and 9.3 sec., and for B and C shocks 8.9 and 9.4 sec. These figures should be diminished by $0.3 \mathrm{sec}$. to allow for the elevation of Mount Wilson, so that we have 8.6 (or 9.0) to compare with Gutenberg's 8.4. At Pasadena the corresponding means for the $A$ and $B$ groups are 9.0 and 9.1 ; there is no correction for height, so that these correspond to the second phase at Mount Wilson. For the other stations (applying a height correction $Z$ ) we find:

\begin{tabular}{|c|c|c|c|}
\hline Station & $\begin{array}{r}\text { Sn-O-O } \\
\text { Group A }\end{array}$ & $\begin{array}{l}0 \Delta-Z \\
\text { roups } \mathrm{B}, \mathrm{C}\end{array}$ & $z$ \\
\hline Palomar & 9.4 & 9.4 & 0.3 \\
\hline Haiwee. . & 9.9 & 8.9 & 0.3 \\
\hline Boulder City. & 10.0 & 10.2 & 0.2 \\
\hline La Jolla & 10.1 & 10.3 & 0 \\
\hline Tinemaha & & 9.6 & 0.3 \\
\hline Santa Barbara. & $8.8,9.9$ & 9.5 & 0 \\
\hline
\end{tabular}

Some of the later readings probably refer to a different phase. There is only a rough agreement; and it is puzzling that the arrival of $\mathrm{Sn}$ for the B and C shocks is not later than for the A shocks.

On the figures, lines have been drawn with the equation $S n-0=9.0+$ $0.220 \Delta$, which fit the plotted points for the B and C shocks quite well, while some for the A group fall below, suggesting that possibly earlier readings could have been selected for the preceding calculation.

Especially on the plot for the B and C shocks there are points which fall close to lines with time given by $6.0+0.25 \Delta$. These have been drawn on the plots. They correspond to the phase formerly denoted as Sm. Gutenberg now denotes this phase as $\mathrm{Sa}$, with time given by $5.5+0.242 \Delta$.

There is probably Sy corresponding to $\mathrm{Py}$, and similarly best recorded at Tinemaha; its travel time is near 80 sec. On the seismograms this is a large, sharp wave standing out clearly from previous smaller motion.

\section{Additional SHocks}

No. 35 is a small shock recorded at the temporary station named Cady, as reported in the preliminary paper. The first motion there was at $22: 17: 22.8$, May 1, 1947. The interval $\mathrm{s}-\mathrm{p}$ is not legible for this shock; but other smaller 
shocks on the same record show an interval of 1.0 sec. or larger. Assuming from this that $p-O=1.4$ sec., so that $O=21: 17: 21.4$, the following are travel times for the other stations:

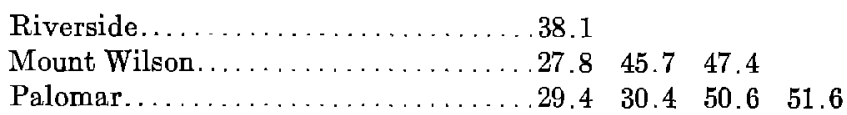

These check fairly well with the arrival times of phases for the B group; agreement is not so good for the A group. The B epicenter is distant $10.5 \mathrm{~km}$. from Cady. A depth of $10 \mathrm{~km}$. would give $D=14.7 \mathrm{~km}$., requiring a travel time of 2.3 sec. The shorter travel time required can only be had by taking a very shallow source somewhat nearer Cady. Since this is a small and imperfectly recorded shock, the entire interpretation remains dubious.

No. 36 is a rather large shock, and certainly originated in this region, but the data appear to conflict. The travel times are as follows, assuming as origin time $05: 43: 40.0$, derived from what appear to be the times of $\mathrm{p}$ and $\mathrm{s}$ at Riverside:

\begin{tabular}{|c|c|c|c|c|c|c|c|}
\hline Riverside. & 21.6 & 22.2 & 23.7 & 28.2 & 37.4 & & \\
\hline Boulder City. & 22.8 & 26.3 & 28.2 & 29.8 & 34.3 & 53.6 & \\
\hline Mount Wilson............... & 25.4 & 27.5 & 27.8 & 29.1 & 31.9 & 45.2 & 47.2 \\
\hline Pasadena. & 27.1 & 28.5 & 39.5 & 43.2 & 47.5 & 47.9 & 50.5 \\
\hline Palomar.. & 27.7 & & & & & & \\
\hline Haiwee. . & $29.1 ?$ & 32.0 & 49.7 & 53.2 & & & \\
\hline Pierce Ferry ... & 33.8 & 35.3 & 37.9 & 39.7 & & & \\
\hline La Jolla. & $35.6 ?$ & 37.3 & 48.4 & 64.6 & 67.2 & 67.9 & \\
\hline$\ldots \ldots \ldots \ldots$ & 39.4 & 41.3 & 42.6 & 46.8 & 49.3 & & \\
\hline Santa Barbara. & 42.0 & 47.7 & 49.7 & 50.7 & & & \\
\hline Tucson. & 78.8 & 80.6 & 96.2 & 101.4 & 112.2 & & \\
\hline
\end{tabular}

Comparison with the tables shows that times at all the California stations check fairly well for Group A, but that Boulder City, Pierce Ferry, and Tucson are much too early. The indication is for an earlier origin time, an epicenter a few kilometers to the northeast, and perhaps a greater depth. Possibly an earlier shock occurred nearer the Lake Mead stations. Unfortunately the recording at Haiwee is very poor; the vertical-component instrument was out of order. The shocks on August 26, December 6, and December 7, 1947, listed in table 9 , may be from the same source.

No. 37 is not strictly one of the Manix series, but is very well located, and by a lucky accident its data serve to fill in some of the gaps in the travel-time curves left by the other shocks. This is due partly to the more westerly epicenter and partly to data from the new installations at Perris, Pomona, Crestline, and China Lake. No. 37 and its aftershock, No. 38, constitute Group D; times are given in table 8. 
The origin time for No. 37 was found as follows:

\begin{tabular}{|c|c|c|c|c|}
\hline Station & $p$ & $s-p$ & $p-0$ & 0 \\
\hline Riverside. & $20: 14: 32.0$ & 14.6 & 20.0 & $20: 14: 12.0$ \\
\hline Perris.... & $: 34.3$ & 15.7 & 21.5 & $: 12.8$ \\
\hline Pomona. . . . . . . . . . . . . & $: 34.0$ & 15.9 & 21.8 & $: 12.2$ \\
\hline Crestline & $: 27,4$ & 10.7 & 14.7 & $: 12.7$ \\
\hline China Lake . . . . . . . . . . . & $: 34.4$ & 15.7 & 21.5 & $: 12.9$ \\
\hline
\end{tabular}

TABLE 8

Observed Travel Times, Shocks of Group D

(Serial numbers and origin times are as given in table 1. Epicenter $34^{\circ} 53^{\prime} \mathrm{N}, 116^{\circ} 37^{\prime} \mathrm{W} . h=16 \mathrm{~km}$.)

\begin{tabular}{|c|c|c|c|}
\hline Station & $\begin{array}{c}\text { Distance } \\
(\mathrm{km} .)\end{array}$ & $\begin{array}{l}\text { Shock } \\
\text { no. }\end{array}$ & Travel times (sec.) \\
\hline Crestline. . . . . . . . . & 92.4 & $\begin{array}{l}37 \\
38\end{array}$ & $\begin{array}{l}14.6 \quad 16.617 .6 \quad 25.325 .9 \\
s-p=11.3 \text { (no absolute time) }\end{array}$ \\
\hline Riverside. . & 120.8 & $\begin{array}{l}37 \\
38\end{array}$ & $\begin{array}{lllll}19.2 & 19.5 & 20.5 & 33.8 & 34.7 \\
19.2 & 20.2 & 24.5 & 33.1 & 33.5\end{array}$ \\
\hline Pomona. . . . . . . & 133.0 & $\begin{array}{l}37 \\
38\end{array}$ & $\begin{array}{llll}21.2 & 24.2 & 37.1 & 38.2 \\
21.8 & 34.0 & 36.5\end{array}$ \\
\hline Perris . & 134.9 & $\begin{array}{l}37 \\
38\end{array}$ & $\begin{array}{llll}21.5 & 24.6 & 32.6 & 37.2 \\
21.7 & 22.1 & 36.8 & \end{array}$ \\
\hline China Lake.... & 136.5 & 37 & $21.622 .025 .0 \quad 37.3$ \\
\hline Mount Wilson... & 151.0 & $\begin{array}{l}37 \\
38\end{array}$ & $\begin{array}{lllllll}24.2 & 25.4 & 30.8 & 33.3 & 41.2 & 43.1 & \\
23.7 & 24.0 & 25.0 & 28.0 & 37.0 & 41.2 & 41.8\end{array}$ \\
\hline Pasadena...... & 164.4 & $\begin{array}{l}37 \\
38\end{array}$ & $\begin{array}{lllllll}25.4 & 25.7 & 26.6 & 27.2 & 44.2 & 44.6 & 47.2 \\
26.1 & 26.8 & 29.1 & 37.9 & 44.6 & 45.3 & 46.1\end{array}$ \\
\hline Palomar... & 171.5 & $\begin{array}{l}37 \\
38\end{array}$ & $\begin{array}{lllll}26.6 & 28.6 & 46 & & \\
26.8 & 28.3 & 47.1 & 48.9 & 49.5\end{array}$ \\
\hline Haiwee........ & 185.2 & $\begin{array}{l}37 \\
38\end{array}$ & $\begin{array}{l}27.8 ? 29.5 \quad 31.6 \quad 49.950 .451 .5 \\
31.5 ? 34.1 ? 51.5 \quad 52.7\end{array}$ \\
\hline Boulder City ... & 202.7 & $\begin{array}{l}37 \\
38\end{array}$ & $\begin{array}{llll}30.4 & 34.4 & 55 & 56.7 \\
35.7 & 57.9\end{array}$ \\
\hline La Jolla. & 231.7 & 37 & $\begin{array}{llllllll}36.9 & 37.6 & 43.1 & 49.8 & 56.4 & 62.8 & 63.7 & 64.3\end{array}$ \\
\hline Overton. & 268.1 & 37 & $33.7 \quad 457982$ \\
\hline Pierce Ferry. . & 273.9 & 37 & 4045476379 \\
\hline Tinemaha... & 286.6 & $\begin{array}{l}37 \\
38\end{array}$ & $\begin{array}{l}39.5 ? \quad 40.2 \quad 43.7 \quad 47.4 \quad 48.851 .4 \quad 58.480 .781 .6 \\
83.3 \quad 87.3 \\
46.1 \quad 69.1 \quad 80.4\end{array}$ \\
\hline Santa Barbara. & 288.2 & 37 & $45.1 \quad 48.6 \quad 50.2 \quad 79.4 \quad 80.3 \quad 84.5 \quad 85.1$ \\
\hline Tueson. & 611.3 & 37 & $\begin{array}{lllllllll}80.5 & 80.8 & 82.2 & 87.4 & 105.4 & 108.8 & 156.0 & 156.8 & 174.8\end{array}$ \\
\hline
\end{tabular}


Here $p-O$ has been found by multiplying $s-p$ by 1.37. The origin time was tentatively taken at $20: 14: 12.8$, and on that basis an epicenter was determined at $34^{\circ} 53^{\prime} \mathrm{N}, 116^{\circ} 37^{\prime} \mathrm{W}$. Distances computed from this epicenter proved to fit very closely to the travel times of most of the principal recorded waves. These times and distances, and those of No. 38, are entered on figures 1 and 3 together with those of Group A; they may be distinguished by their different abscissas.

The following shows the comparison of observed and calculated times of first motion (p or Pn, assuming $h=16 \mathrm{~km}$. as for Group A, and values of $K$ and height corrections as for No. 14).

\begin{tabular}{|c|c|c|c|}
\hline Station & $\Delta \mathrm{km}$. & $P-O$ calc. & $o-C$ \\
\hline Crestline. & 92.4 & 14.8 & -0.2 \\
\hline Riverside. & 120.8 & 19.2 & 0.0 \\
\hline Pomona. & 133.0 & 21.1 & +0.1 \\
\hline Perris. & 134.9 & 21.4 & +0.1 \\
\hline China Lake.. & 136.5 & 21.7 & -0.1 \\
\hline Mount Wilson. & 151.0 & 24.2 & 0.0 \\
\hline Pasadena...... & 164.4 & 26.0 & -0.6 \\
\hline Palomar..................... & 171.5 & 26.6 & 0.0 \\
\hline Haiwee. . & 185.2 & 28.1 & $-0.3 ?$ \\
\hline Tucson... & 611,3 & 80.1 & +0.4 \\
\hline
\end{tabular}

The unexpectedly early first motion at Pasadena is similar to that recorded for other shocks in this study. The first motion at Haiwee is doubtful; the wave measured is extremely small and is involved in microseisms. The beginning of the Tinemaha seismogram is small and is involved in disturbance; the doubtful first reading is a little earlier than the time to be expected in the absence of delay by the root of the Sierra Nevada. These observations suggest some peculiarity existing along the paths from this epicenter to Haiwee and Tinemaha, but absent along the adjacent paths from the A and $B$ epicenters.

Search of the records to the present writing (May, 1950) has identified no other shocks available for the purposes of this paper. Some which might have been used have had to be rejected because of imperfect recording at one or more important stations, owing either to instrumental causes or to microseismic disturbance. Shocks of magnitude less than 4 are difficult to use because it is constantly uncertain whether the first recorded motion on the seismogram is the earliest seismic wave. Shocks more than $15 \mathrm{~km}$. distant from the principal epicenters cannot safely be included in the study of travel times, and have only a remote bearing on the geological problem of the Manix shocks. Some of the smaller recorded shocks are probably on the northwestern continuation of the line of epicenters, and some appear to be to the east. 
TABLE 9

Manix Earthquakes of Magnitude 3.0 or Greater, AprII, 1947-AprL, 1950

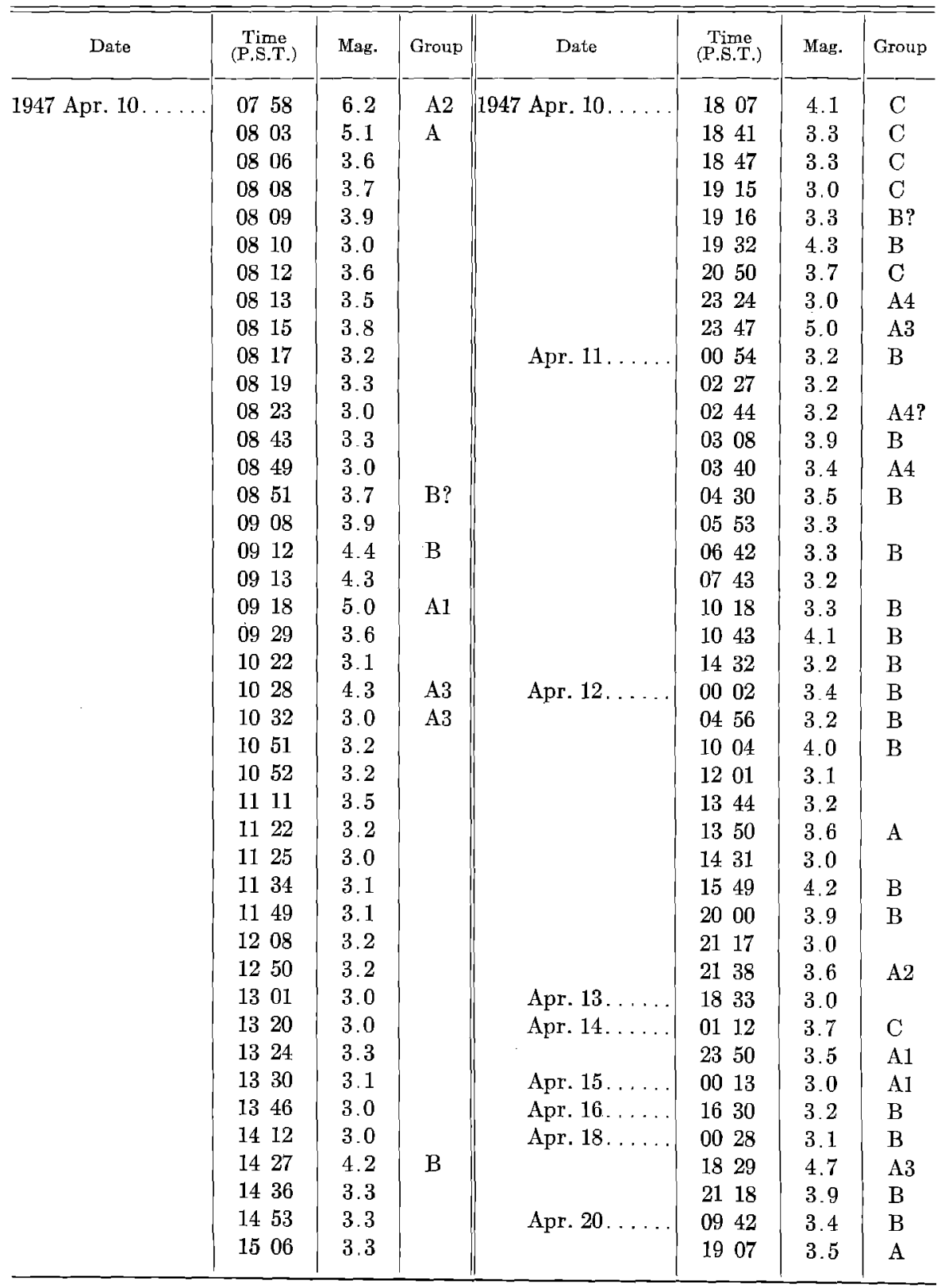


TABLE 9-Continued

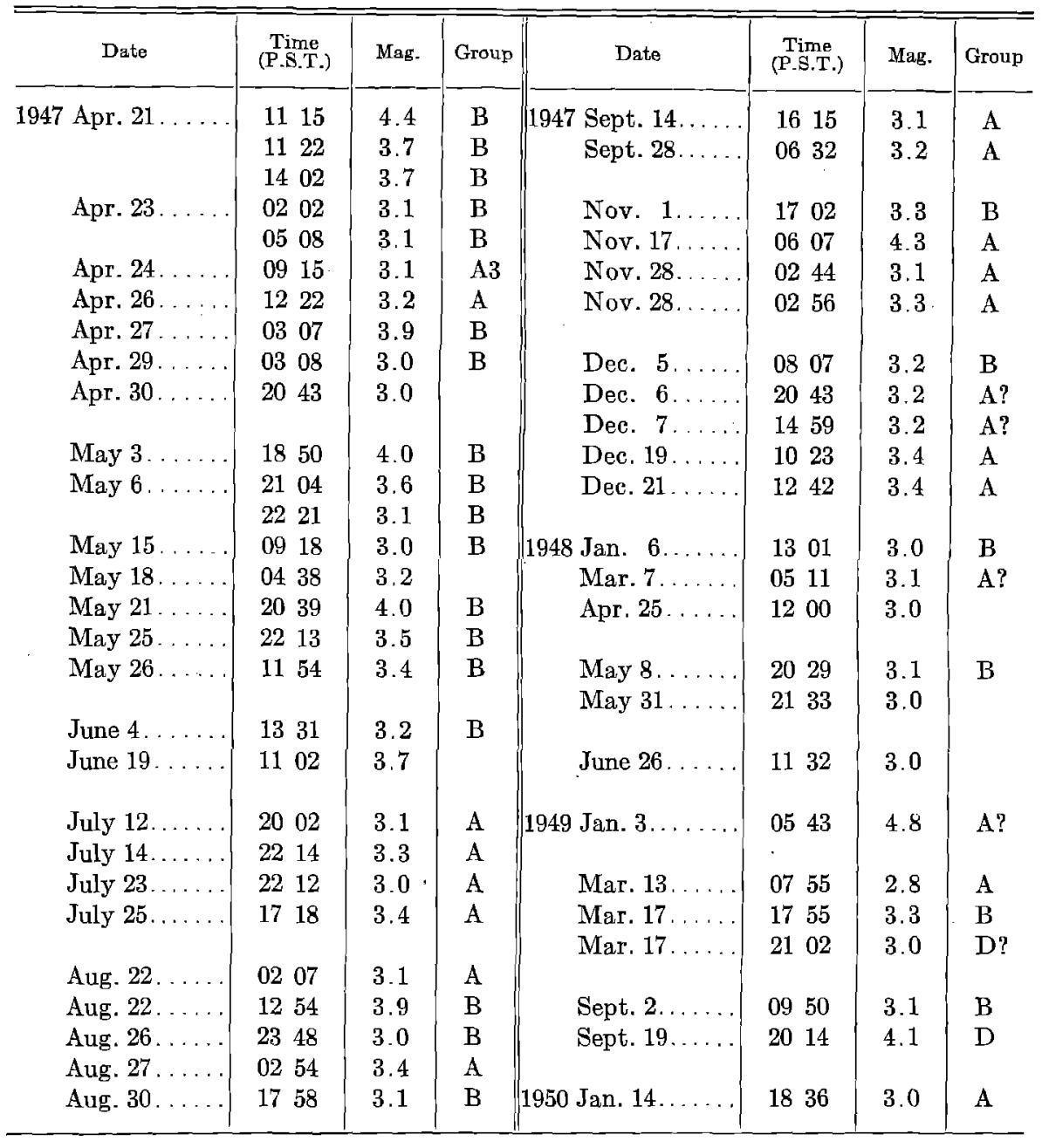

\section{Catalogue of the Manix Shocks}

Prior to April 10, 1947, only a few small earthquakes had been doubtfully located in the immediate region of the Manix epicenters. Table 9 covers the following three years (to the end of April, 1950), listing shocks of magnitude 3.0 or greater. Origin times are given to the minute. Where possible, assignment to groups is indicated. No such assignment can be made for shocks immediately following the main earthquake, since the first motions cannot be read accurately, nor for any of the smaller shocks for which there is deficient 
recording or exceptional microseismic disturbance. For a few shocks Group A can be indicated without any satisfactory differentiation among its subgroups. Shocks marked A? appear to have epicenters east of the Manix area.

\section{Nature of First Recorded Motions}

For No. 1, the main shock, initial compressions were recorded at Santa Barbara, Fresno, and Tucson; initial dilatations were recorded at Riverside, Mount Wilson, Pasadena, Haiwee, La Jolla, and Tinemaha.

For Tinemaha and Haiwee this information is opposite to that given in the preliminary paper. The vertical-component seismograms there show lines badly tangled with later large motion, and interpretation is difficult. That reported here agrees with the indication of the less sensitive horizontalcomponent instruments. It is the first short-period impulse; the large, longperiod impulse is in the other direction.

Except at Pasadena and Mount Wilson, the first motions of the larger aftershocks are quite constant in character. Initial compressions are regularly recorded at Haiwee and Tinemaha; No. 14 has a compression at Tucson. Initial dilatations are regular at Cady, Cave Mountain, Old Woman Springs, Riverside, and La Jolla. At Pasadena most of the first motions are dilatations, but compressions are found for Nos. 2, 3, 4, and 16. At Mount Wilson also dilatations are the rule, but clear exceptions are provided by initial compressions for Nos, 2, 4, 7, 8, 9, 17, and 18. Several of these latter belong to Group C.

The first motions of the majority of aftershocks are consistent either with left-hand strike-slip on the Manix fault, or with right-hand strike-slip on a fault following the line of epicenters (striking about $\mathrm{N} 30^{\circ} \mathrm{W}$ ). The main shock does not fit so well, on account of the initial dilatations at Haiwee and Tinemaha.

\section{Magnitude of the Principal Earthquake}

In the preliminary paper a tentative magnitude of 6.8 was given for shock No. 1. As data were received from more distant stations this was seen to be too large. The high figure was suggested by the large amplitudes recorded on the strong-motion seismograms at Pasadena (fig. 5). These large amplitudes represent long-period motion; the maximum of the recorded vibrations of shorter period is about $2.5 \mathrm{~mm}$., which at the epicentral distance of $175 \mathrm{~km}$. corresponds to magnitude 6.2 .

Comparison was also made between the trace amplitudes of the $\mathrm{P}$ group of Nos. 1 and 14 as recorded on the horizontal-component seismograms at Tinemaha, Haiwee, La Jolla, and Santa Barbara. The ratio of the amplitudes of corresponding waves for the two shocks ranged from about 10:1 to 15:1, the corresponding logarithms being 1.0 to 1.2. The larger predominate; if this is accepted, then, since the magnitude of No. 14 is well determined as 5.0, that of No. 1 is found to be 6.2 . 
Amplitudes of the maximum recorded surface waves were reported by a number of distant stations, with the following results:

\begin{tabular}{|c|c|c|c|c|c|c|c|}
\hline Station & $\Delta($ deg. $)$ & $A_{\mathrm{N}}$ & $\underset{A_{\mathbb{E}}}{\operatorname{MicnoNB}}$ & $A_{\mathbf{Z}}$ & $T$ (sec.) & $\begin{array}{c}\text { Station } \\
\text { correction }\end{array}$ & Magnitude \\
\hline Alicante. & 84 & & 13 & & 20 & -0.2 & 6.0 \\
\hline Budapest. & 89 & 12 & 12 & & 20 & -0.1 & 6.2 \\
\hline Cartuja.. & 85 & 48 & & & 18 & -0.1 & 6.6 \\
\hline Cheb.... & 84 & & 25 & & 17 & & 6.4 \\
\hline \multirow[t]{2}{*}{ De Bilt.... } & 79 & 25 & 25 & & 22 & -0.2 & 6.3 \\
\hline & & 30 & 55 & 30 & 18 & & 6.6 \\
\hline Durham. & 74 & 15 & 17 & & 14 & & 6.3 \\
\hline \multirow[t]{3}{*}{ Kew..... } & 77 & 51 & & & 24 & -0.1 & 6.6 \\
\hline & & & 16 & & 18 & & 6.1 \\
\hline & & & & 32 & 19 & & \\
\hline $\mathrm{La} \mathrm{Paz} \ldots$ & 69 & & 14 & & 20 & +0.1 & 6.2 \\
\hline Moscow. & 87 & 11 & & & & & 6.1 \\
\hline Praha. . & 85 & 12 & 10 & & 20 & +0.1 & 6.4 \\
\hline Riverview. & 111 & & 3 & 4 & 19 & +0.2 & 6.0 \\
\hline Sverdlovsk & 88 & 17 & & & & +0.1 & 6.4 \\
\hline Tortosa... & 85 & 2 & 2 & & 15 & +0.4 & 5.9 \\
\hline \multirow[t]{2}{*}{ Uppsala. } & 78 & 4.7 & & & 21 & & 5.8 \\
\hline & & & 4.0 & & 20 & & \\
\hline
\end{tabular}

These magnitudes are derived from the tables given by Gutenberg (1945). The mean is between 6.2 and 6.3 .

Cartuja reports an $\mathrm{S}$ in the $\mathrm{N}$ component with amplitude of 2 microns and period of 9 seconds; this corresponds to a magnitude of 6.1 or 6.2 .

The rating 6.2 is adopted as the magnitude of shock No. 1 .

\section{Teleseismic Registration of the Principal Eartheuake}

Although epicenter and origin time for No. 1 are very well determined, caution must be exercised in using its observed times at distant stations. This is owing to the occurrence of a deep shock in the region of the Kermadec Islands at about $07: 45.7$ P.S.T. (15:45.7 G.C.T.). The first motion due to this shock precedes that due to the Manix earthquake at all stations. Later phases of the Manix shock at large distances may therefore be confused with $\mathrm{S}$ and other phases of the Kermadec shock. At stations in New Zealand and Australia the record of the Manix shock is largely obscured.

In America and Europe, $\mathrm{P}$ of the Manix shock is recorded without confusion. For the following comparison its origin time has been taken at 15:58:06 G.C.T., from which the "observed" travel times are derived. The epicenter is $34^{\circ} 59^{\prime} .5 \mathrm{~N}, 116^{\circ} 33.5 \mathrm{~W}$. The geocentric direction cosines for this point, as used in the International Seismological Summary, are computed to be:

$$
\mathrm{A}=-.36710 \quad \mathrm{~B}=-.73446 \quad \mathrm{C}=+.57086
$$


Miss Marion Reid has computed the geocentric arc distances to the observing stations, using the revised table of geocentric direction cosines published by Comrie (1950). The following direction cosines, not included in the table just cited, have been determined at Pasadena:

\begin{tabular}{|c|c|c|c|}
\hline & $a$ & b & c \\
\hline & -.3258 & -.5882 & +.740 \\
\hline & -.4073 & -.6421 & -.6494 \\
\hline & +.1355 & -.7498 & +.6477 \\
\hline Bog & +.2736 & -.9585 & +.0800 \\
\hline
\end{tabular}

TABLE 10

Travel Times of the Manix Earthquake

\begin{tabular}{|c|c|c|c|c|c|c|c|}
\hline Station & $\Delta$ & $\begin{array}{l}P-O \\
\text { (obs.) }\end{array}$ & $O-C$ & Station & $\Delta$ & $\begin{array}{l}P-O \\
(\text { obs.) }\end{array}$ & $o-C$ \\
\hline Santa Clara. & $\begin{array}{c}\text { deg. } \\
4.9\end{array}$ & $\begin{array}{ll}m . & s \\
01 & 13\end{array}$ & $\begin{array}{l}\text { sec. } \\
+1\end{array}$ & Bogotá. & $\begin{array}{c}d e g . \\
49.5\end{array}$ & $\begin{array}{ll}m . & s . \\
08 & 56\end{array}$ & $\begin{array}{l}\text { sec. } \\
+3\end{array}$ \\
\hline Berkeley. . & 5.4 & 0120 & 0 & La Paz. & 68.8 & 1109 & +1 \\
\hline Tucson. & 5.5 & 0121 & 0 & Kew. & 77.4 & 1157 & 0 \\
\hline Shasta Dam & 7.8 & 0149 & -1 & Uppsala. & 78.3 & 1226 & +13 \\
\hline Grand Coulee. & 13.0 & 0309 & 0 & De Bilt. & 79.4 & 1211 & +2 \\
\hline Victoria... & 14.3 & 0333 & +7 & Helsinki . & 80.0 & 1210 & -2 \\
\hline Saskatoon. . & 18.5 & 0419 & 0 & Paris. & 80.5 & 1214 & 0 \\
\hline Florissant. & 21.3 & 0450 & +1 & Lisbon. & 80.6 & 1211 & -4 \\
\hline St. Louis. & 21.4 & 04.9 & -1 & Toledo.. & 82.8 & 1226 & 0 \\
\hline Tacubaya. & 21.9 & 0457 & +1 & Clermont-Ferrand & 82.9 & 1227 & +1 \\
\hline Chicago. & 23.6 & 0511 & -2 & Strasbourg. & 83.1 & 1229 & +2 \\
\hline Sitka. & 25.4 & 0531 & 0 & Stuttgart. & 83.6 & 1231 & $\begin{array}{llll}+1 & & & \end{array}$ \\
\hline New Kensington. & 29.6 & 0604 & -3 & Basel.. & 83.8 & 1229 & -2 \\
\hline Ottawa.. & 32.6 & 0631 & -2 & Zurich. & 84.4 & 1234 & 0 \\
\hline Philadelphia. & 33.0 & 0637 & 0 & Malaga. & 84.8 & 1236 & 0 \\
\hline Fordham.... & 33.9 & 0643 & -2 & Praha. & 84.9 & 1240 & +4 \\
\hline Shawinigan Falls. & 34.6 & 0645 & -7 & Cartuja.... & 85.0 & 1239 & -2 \\
\hline Harvard. & 35.5 & 0658 & 0 & Almeria.. & 85.9 & 1243 & +2 \\
\hline Weston & 35.7 & 0704 & +4 & Moscow. & 86.9 & 1246 & 0 \\
\hline Seven Falls. & 36.1 & 0705 & +1 & Sverdlovsk. & 88.5 & 1254 & 0 \\
\hline San Juan. & 47.5 & $08 \quad 40$ & +2 & & & & \\
\hline
\end{tabular}

The travel times are calculated from the distances by use of the data given by Gutenberg and Richter (1934), except at the three nearest stations, where $P-O=5.4+\Delta(\mathrm{km}) /$.8.2 . Results are given in table 10 . In the column headed $O-C$, the notation -3 means that the observed arrival time is 3 sec. earlier than that calculated in this way. The agreement is excellent in general, and is even better when it is recalled that the best value for the origin time is almost a half second earlier than that used. Since the standard travel times are intended to represent a shock originating at a depth of $25 \mathrm{~km}$. instead of the 
$16 \mathrm{~km}$. found for this shock, the times at distant stations are perhaps about one second earlier, on the average, than should be expected.

\section{Note on Tectonic Implications}

Buwalda and Richter (1948) have presented an account of the trace phenomena of the Manix earthquake, with some observations on the geology of the area. Field work continues, with the purpose of clarifying problems raised by the instrumental results here reported, preparatory to more adequate geological discussion.

Inset maps on figures 1 and 2 show the relation of located epicenters to the Manix fault, along which trace phenomena were found. Within the limits of error, epicenters of the $A, B$, and $C$ groups are aligned as indicated by the preliminary investigation, suggesting an aetive structure striking about $30^{\circ}$ west of north, at a large angle to the Manix fault. No located epicenters are distributed along or parallel to the Manix fault.

This unexpected result has no close analogue in seismological literature. Some earthquakes have been accompanied by visible displacements and other trace phenomena on two faults forming a large angle. The best studied instance is that in the Tango district of Japan on March 7, 1927; but aftershocks then originated along both faults.

It is natural to inquire into the possibility of systematic error. Oversimplified assumptions about regional crustal structure, implicit in the epicentral determinations, may indeed be responsible for minor inaccuracies in location, but correcting such errors should only shift all the epicenters in the same way, leaving the strike of the indicated active feature practically unchanged.

The instrumental results do not necessarily conflict with the field observations. Reliff in shear of a regional north-south compression, involving both a major right-hand displacement along a deep-seated fracture striking $\mathrm{N} 30^{\circ} \mathrm{W}$, and a minor left-hand strike-slip along the Manix fault, will account for all the data, including the directions of initial motion at the recording stations, with a high degree of mechanical consistency. Further field study, or possibly the occurrence of new earthquakes, may make a more complex hypothesis necessary. Failure to find aftershocks along the Manix fault is not an insuperable objection, since only the larger shocks can be located precisely.

The active line almost certainly crosses the Manix fault. The A2 epicenter, which is that of the main shock, is actually north of the fault, but at a distance which is within the limits of error. However, the A4 epicenter is a little more to the north; and small shocks have been located with uncertainty still farther in that direction.

The vicinity of the line of epicenters, some five miles in extent, has been searched on the ground. No fault has been found at the surface, but the basement rocks are largely covered by fan material, stream deposits, and beds of 
the Manix series. The structure is complicated, and striking changes in petrology of the occasional bedrock exposures occur within short distances; however, there is no evident alignment with a trend near $30^{\circ}$ west of north.

The Group D epicenter is presumably unrelated to the Manix shocks. It is near the probable continuation of a fault which may be seen on the geologic map of California (Jenkins, 1938), striking northwesterly through the mountains south of the Santa Fe railroad line. This and parallel faults are related to a broad active zone, with many located earthquakes from 1929 to date, extending northwesterly across the Mojave Desert, including the towns of Yermo and Barstow. The Manix epicenters are well outside this zone. To the southeast in the vicinity of the Ludlow, Bagdad, and Amboy stations there is another active region, in which occurred the largest located shock in the Mojave Desert area excluding the principal Manix earthquake-that of July 18, 1946 (magnitude 5.6).

\section{The Figures}

Figure 1 shows the travel times, $t-O$, for all shocks of Groups $A$ and $D$, plotted against distance (to $300 \mathrm{~km}$.). Each single time observation has been indicated by a short horizontal line. Where times read for several shocks coincide to the tenth of a second, the line has been lengthened. Travel-time curves have been drawn according to the equations given in an earlier section. Many observations fit these curves, but other alignments are suggested, particularly between the $P$ and $S$ groups, where reflected waves of various types may be expected. The inset map shows the epicenters in relation to some of the principal topographical and cultural features, and to the Manix fault. Figure 2 is a corresponding plot and map for the $\mathrm{B}$ and $\mathrm{C}$ groups. Times observed for shock No. 17 have been distinguished by solid dots, except where they coincide closely with those of several other shocks.

Figure 3 shows times for the $\mathrm{P}$ phases of the $\mathrm{A}$ and $\mathrm{D}$ shocks individually on a larger scale. Those on the main plot, from 160 to $200 \mathrm{~km}$., are for observations at Mount Wilson, Pasadena, Haiwee, Palomar, and Boulder City. Those on the inset, near $130 \mathrm{~km}$, are for Riverside, Pomona, Perris, and China Lake (the last three for Group D only). The same curves are drawn as for figure 1; these do not allow for height corrections, which accounts for some apparently late readings.

Figure 4 is drawn for the $\mathrm{B}$ and $\mathrm{C}$ groups, corresponding to the main plot of figure 3 . Observations for shock No. 17 are distinguished by larger dots. There is strikingly good agreement among the observations of the several shocks. One of the very early times at Boulder City probably belongs to a smaller preceding shock recorded at the other stations.

Figure 5 reproduces representative seismograms. These are identified by the initial of the recording station (using $P$ for Pasadena and Po for Pomona), and 


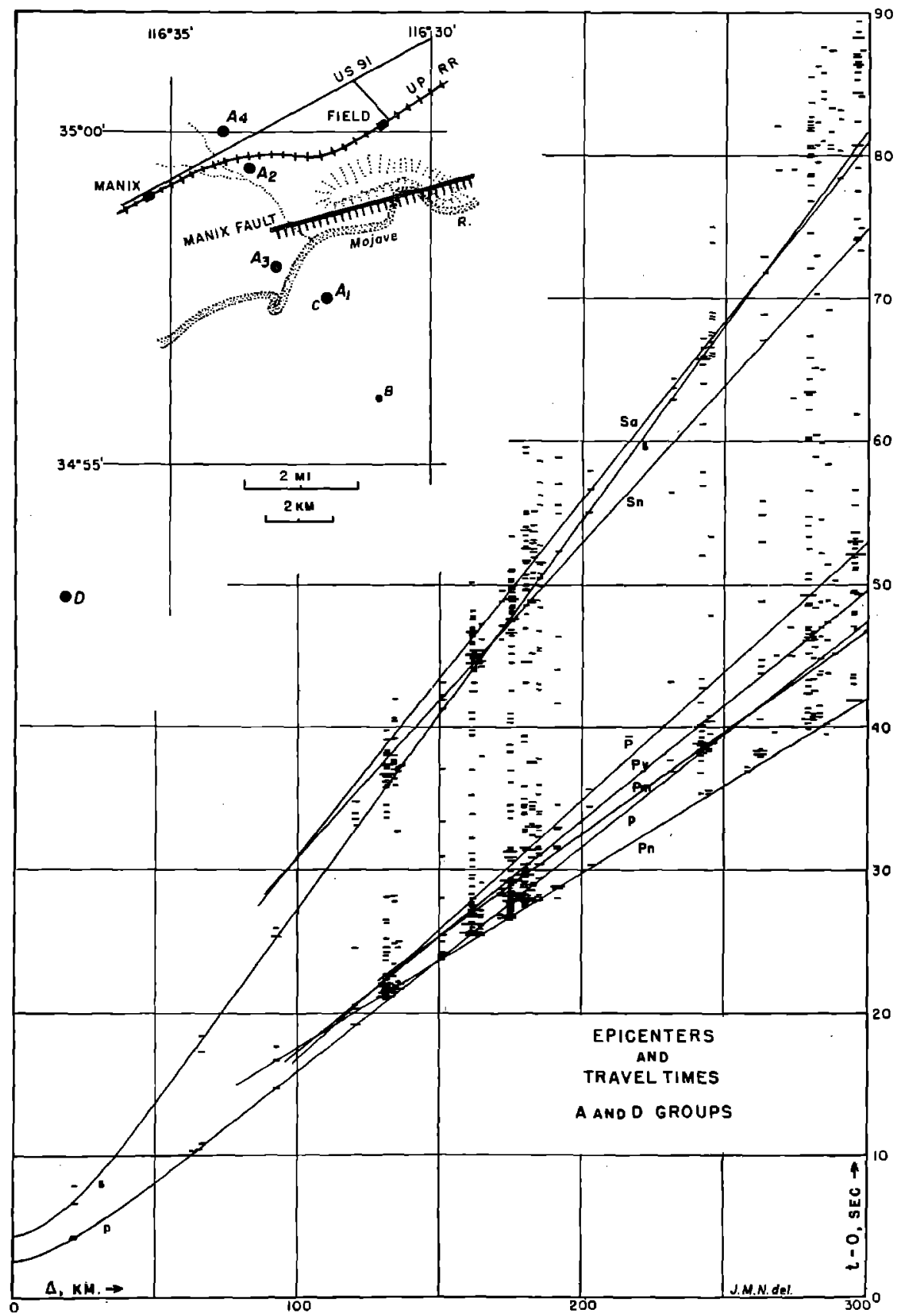

Fig. 1. General travel-time plot, shocks of Groups A and D, to $300 \mathrm{~km}$. Lengthening of horizontal lines indicates coincidenee for several shocks. Inset, sketch map showing epicenters. 


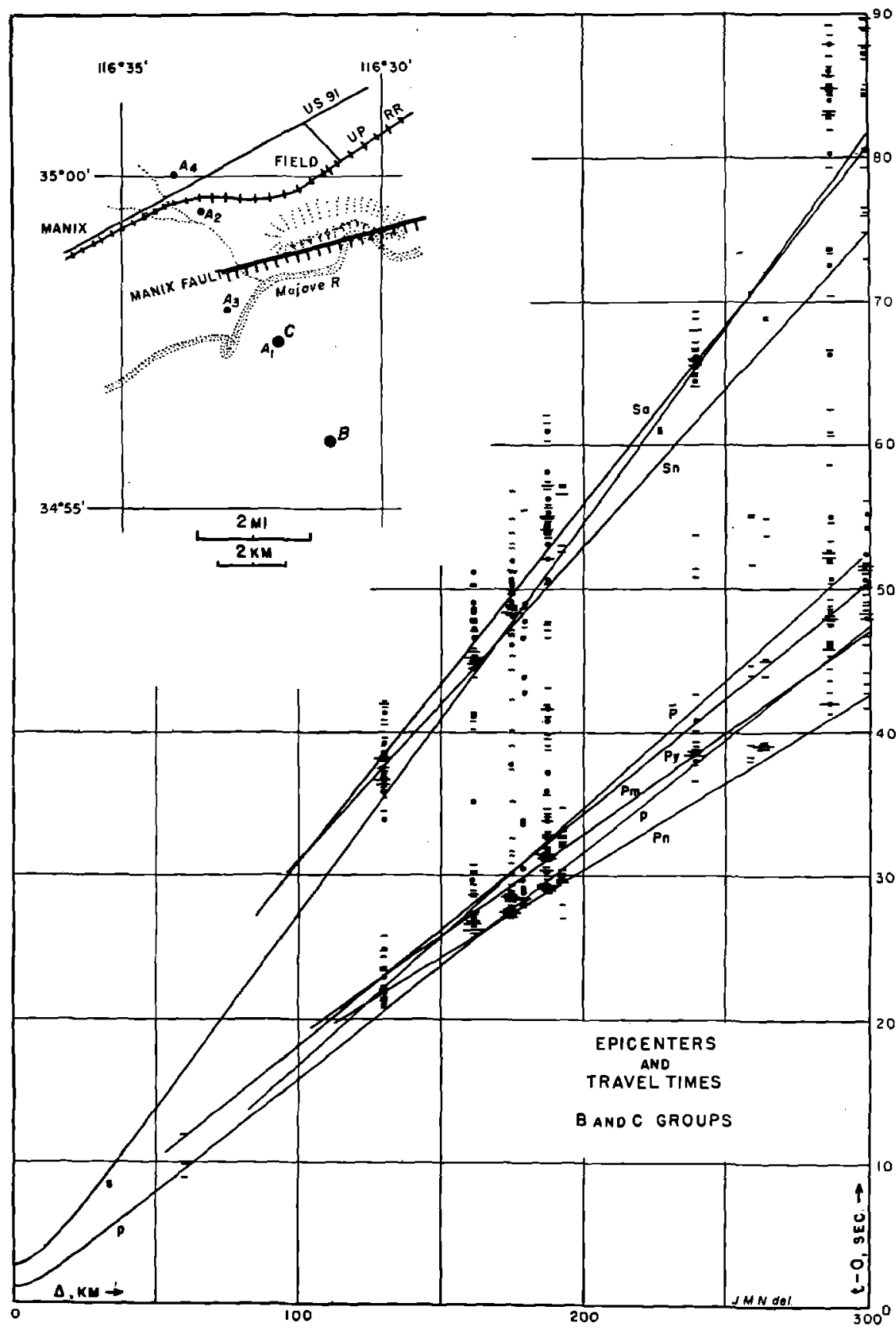

Fig. 2. General travel-time plot, shocks of Groups B and C, to $300 \mathrm{~km}$. Lengthening of horizontal lines indicates coincidence for several shocks. Solid dots are for No. 17. Inset, sketch map showing epicenters. 


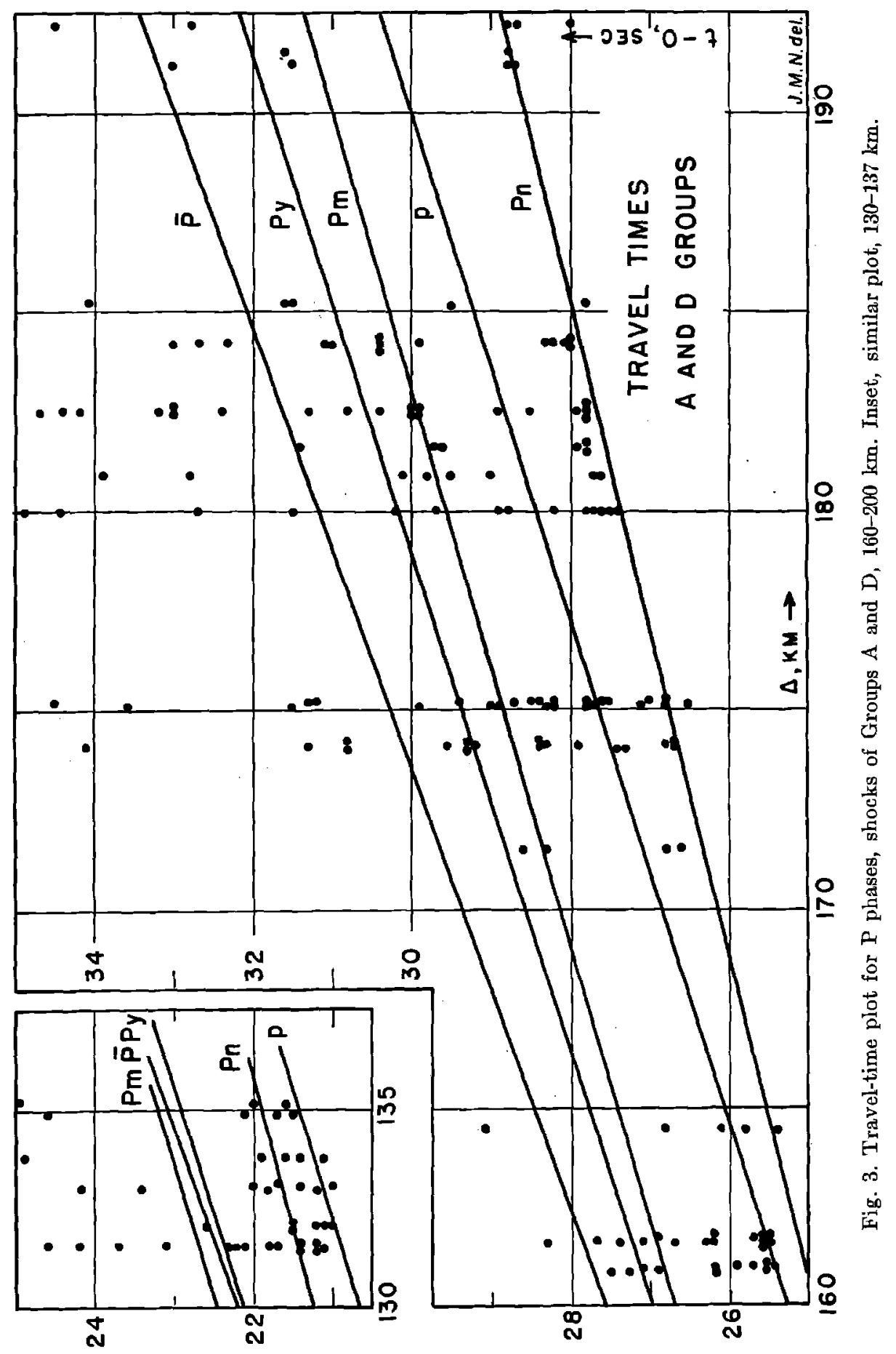




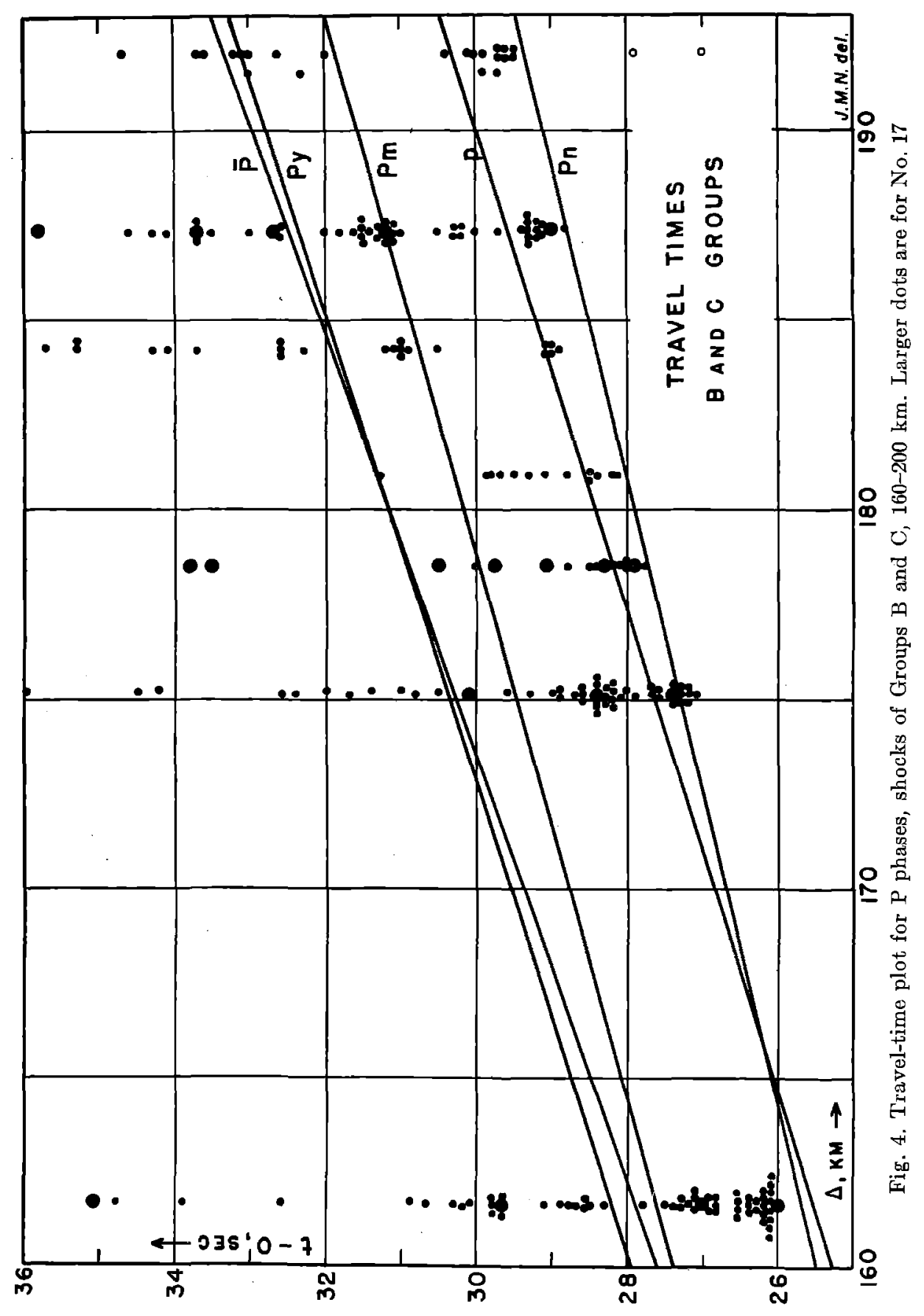




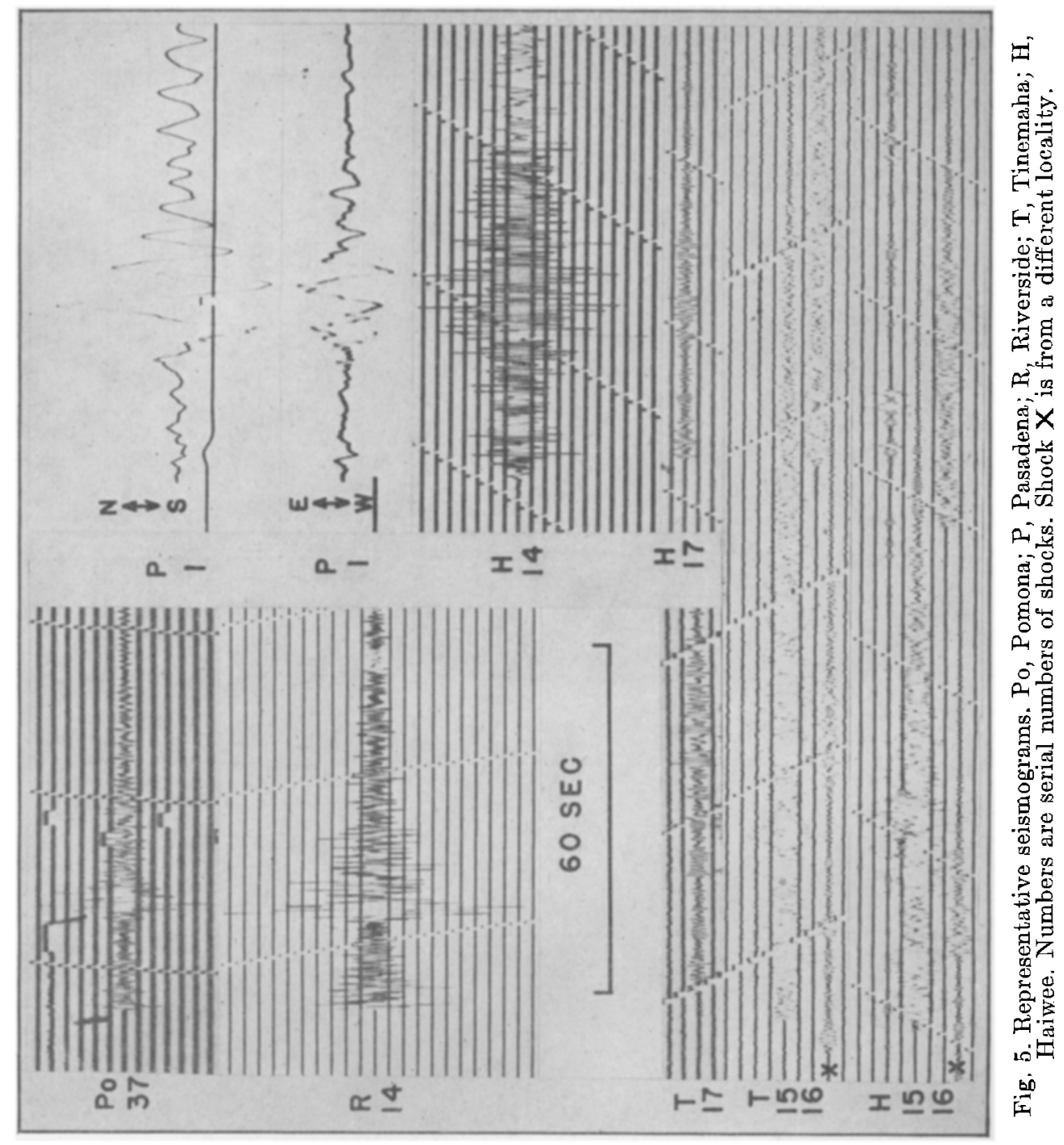


the serial numbers of the shocks shown. An $\mathrm{X}$ indicates a shock originating at 03:53:08, April 11, 1947, near 34 $07^{\prime} \mathrm{N}, 116^{\circ} 41^{\prime} \mathrm{W}$ (San Bernardino Mountains, not far from Mount San Gorgonio). Except at Pasadena, the clocks mark the record twice each minute; the time interval between corresponding points on successive lines is 15 minutes. Drums rotate at $60 \mathrm{~mm} / \mathrm{min}$. and the original space between lines is $2.5 \mathrm{~mm}$. Remarks are as follows:

Pomona, shock 37, Group D, vertical component. Distance $133.0 \mathrm{~km}$. The very sharp arrival 3 seconds following $\mathrm{p}$ is the phase originally identified by Gutenberg (1944) as S33P, now designated S28P. The data of the Manix shocks do not suffice to draw a time-distance curve for this reflected wave. The double impulse at the beginning of the $\mathbf{S}$ group indicates $\mathrm{s}$ followed by a larger (and slightly early) Sn.

Riverside, shock No. 14, Group A3. Distance $131.6 \mathrm{~km}$. N-S component; ground motion north is upward on the seismogram. First motion is $\mathrm{p}$; $\mathrm{Pn}$ (?) follows after 0.7 second. $\mathrm{S} 28 \mathrm{P}$ is recorded sharply; the sharp smaller phase between $\mathrm{Pn}$ and $\mathrm{S} 28 \mathrm{P}$ may be S35P. The large $\mathrm{Sn}$ is again preceded by a smaller but sharp s (not represented in table 4).

Pasadena, shock No. 1, Group A2. Distance $175.1 \mathrm{~km}$. Horizontal-component strong-motion instruments. Free period 10 seconds, static magnification 4, damping nearly critical. Direction of ground displacements as indicated on the figure.

Haiwee, shock No. 14, Group A3. Distance $182.5 \mathrm{~km}$. N-S component; ground motion south is upward. The small first motion, one second after the beginning of the clock mark, is Pn; the next, also small, after one second, may be $\mathbf{p}$ (or c). Pm begins about two seconds after Pn; it is much less sharp in this horizontal component than in the vertical component. The large maximum wave of the P series may be S28P.

Tinemaha, shocks Nos. 15 and 17, Group B. Distance $286.7 \mathrm{~km}$. Vertical component (at Tinemaha and Haiwee upward motion on these seismograms corresponds to upward motion of the ground). The small, sharp but late $\mathrm{Pn}$ is followed after 6 seconds by the large sharp Py. Note the large unidentified phase 24 seconds following Pn (travel time, 66 sec.). The sharply recorded S waves are at 38 and 44 seconds after Pn.

Haiwee, shocks Nos. 15 and 17, Group B. Distance $187.3 \mathrm{~km}$. Vertical component. No. 15 clearly shows the interval of 2 seconds between Pn and Pm. For No. 17 the obvious first motion is Pm, but the preceding Pn has been found and measured. Sa (which corresponds to $\mathrm{Pm}$ ) is recorded 23 seconds following Pn (21 seconds after Pm) for both shocks.

Tinemaha, shock No. 16, Group A4. Distance $278.0 \mathrm{~km}$. Vertical component. This shows Py following 5.3 seconds after Pn, which is very small and of short period. Some of the numerous sharp impulses between the $\mathrm{P}$ and $\mathrm{S}$ groups probably represent reflected waves. 
Haiwee, shock No, 16, Group A4. Distance $178.8 \mathrm{~km}$. Vertical component. The evident sharp impulse which would ordinarily be read as the first motion is $\mathrm{Pm}$. On the original record $\mathrm{Pn}$ was read with difficulty 1.9 seconds earlier. There is a slightly clearer small motion $0.4 \mathrm{sec}$. earlier than $\mathrm{Pm}$, which may be c (or p). The sharp phase 5 seconds after Pm is probably S28P. The first clear $\mathrm{S}$ wave, 23 seconds after $\mathrm{Pm}$, is $\mathrm{Sa}$.

\section{ACKNOWLEDGMENTS}

For data used in this investigation the authors are under especially heavy indebtedness to the U. S. Coast and Geodetic Survey; notably to Mr. Frank Werner and Dr. D. S. Carder, who have supplied readings from the seismograms at the Lake Mead group of stations. Original seismograms written at Tucson, available on loan at Pasadena, have been of great value. For Berkeley and Fresno, readings have been supplied by Professor Perry Byerly and Mr. John E. Meeker.

Mrs. Carla Maurer carried out the initial measurements on many of the seismograms studied. Routine measurements for shocks during 1949 were made by Miss Marion Reid, who has computed and constructed tables 9 and 10 from the data, as well as contributing much typing, computing, and other work toward the preparation of the manuscript. The final copy has been typed by Mrs. Frances Andrews.

The authors are grateful to Dr. Beno Gutenberg for much valuable discussion, and for his assistance in the correlation of this investigation with his revision of the standard travel times for southern California.

Dr. J. P. Buwalda has advised and directed field work by the authors and others, results of which are intended for a separate publication. His interest in the possible significance of the instrumental findings has been most stimulating and encouraging.

Special acknowledgment goes to Mr. F. E. Lehner, who set up and operated the temporary stations at Old Woman Springs, Cave Mountain, and Cady, with the assistance of Messrs. Ralph Gilman, B. F. Howell, and S. T. Martner.

We also have to thank the directors of many seismological stations for the continuing exchange of their bulletins for those issued from Pasadena, which makes possible the study of travel times embodied in table 10 , as well as furnishing data for determining the magnitude of the principal earthquake.

\section{Summary}

Readings from seismograms of thirty-eight shocks occurring on the Mojave Desert near Manix, California, are tabulated, plotted, and discussed. For a large proportion of the shocks (Groups $A$ and $D$ ), the most clearly identified seismic waves have travel times as follows (times in seconds, $\Delta$ in kilometers): 


$$
\begin{array}{ll}
\mathrm{p}-\mathrm{O}=D / 6.34 & \overline{\mathrm{P}}-\mathrm{O}=-1.2+0.1799 \Delta \\
\mathrm{Pn}-\mathrm{O}=5.4+0.12195 \Delta & \mathrm{s}-\mathrm{O}=D / 3.67 \\
\mathrm{Pm}-\mathrm{O}=3.9+0.1427 \Delta & \mathrm{Sn}-\mathrm{O}=9.0+0.220 \Delta \\
\mathrm{Py}-\mathrm{O}=1.2+0.1610 \Delta & \mathrm{Sa}-\mathrm{O}=6.0+0.25 \Delta
\end{array}
$$

\begin{tabular}{|c|c|c|}
\hline Group & Lat. $\mathrm{N}$ & Long. W \\
\hline A1. & $34^{\circ} 57^{\prime} .5$ & $116^{\circ} 32^{\prime}$ \\
\hline A2. & 3459.5 & 11633.5 \\
\hline A3. & 3458 & 11633 \\
\hline A4. & 3500 & 11634 \\
\hline B.. & 3456 & 11631 \\
\hline C. & 3457.5 & $116 \quad 32$ \\
\hline D. & $34 \quad 53$ & $116 \quad 37$ \\
\hline
\end{tabular}

$D$ is calculated from $\Delta$ assuming a depth of $16 \mathrm{~km}$.

For the remaining shocks (Groups $B$ and $C$ ), the constant terms in the equations for $\mathrm{Pn}, \mathrm{Pm}, \mathrm{Py}$ are increased to $6.0,4.5$, and 2.2, respectively; the other equations are unchanged, but $D$ is calculated for a depth of $10 \mathrm{~km}$.

The Group A shocks are assigned to four subgroups. Epicenters are as follows:

Epicenters A1 to $\mathrm{B}$ follow an alignment striking about $\mathrm{N} 30^{\circ} \mathrm{W}$, crossing the Manix fault at a large angle. No shocks are located elsewhere along the Manix fault, but the smaller shocks cannot be placed accurately.

The principal earthquake, of magnitude 6.2 , is assigned to the $\mathrm{A} 2$ epicenter, with origin time $07: 58: 05.6$ P.S.T. (15:58:05.6 G.C.T.), April 10, 1947. This agrees well with the times recorded at distant stations. A catalogue is given listing all subsequent shocks of magnitude 3.0 or greater in the area to the end of April, 1950, with assignment to one of the groups when possible.

Recorded initial compressions and dilatations at the several stations are equally consistent with right-hand strike-slip on a hypothetical fault following the line of located epicenters, or with left-hand strike-slip on the Manix fault; the latter displacement was actually found. It is suggested that both occurred.

Representative seismograms are reproduced.

\section{REFERENCES}

Buwalda, J. P., and C. F. Richter

1948. "Movement on the Manix (California) Fault on April 10, 1947" (abstract), Bull. Geol. Soc. Am., 59:1367.

Carder, D. S.

1948. "Travel Times in the Lake Mead Region, Arizona and Nevada," Earthquake Notes, $20: 8$.

Comrie, L. J.

1950. The Geocentric Direction Cosines of Seismological Observatories. Kew Observatory, Richmond, Surrey. viii $+14 \mathrm{pp}$. 
GutenBerg, B.

1944a. "Travel Times of Principal P and S Phases over Small Distances in Southern California," Bull. Seism. Soc. Am., 34:13-32.

1944b. "Reflected and Minor Phases in Records of Near-by Earthquakes in Southern California," Bull. Seism. Soc. Am., 34:137-160.

1945. "Amplitudes of Surface Waves and Magnitudes of Shallow Earthquakes," Bull. Seism. Soc. Am., 35:3-12.

1951. "Revised Travel Times in Southern California," Bull. Seism. Soc. Am., 41:143163.

GutenberG, B., and C. F. RiCHTER

1934. "On Seismic Waves" (first paper), Gerlands Beitr. z. Geophysik, 43:56-133.

Jenkins, Olaf $P$.

1938. Geologic Map of California. Scale 1:500,000. 6 sheets. Div. of Mines, San Francisco.

RichTER, C. F.

1947. "The Manix (California) Earthquake of April 10, 1947," Bull. Seism. Soc. Am., $37: 171-179$.

1950. "Velocities of P at Short Distances," Bull. Seism. Soc. Am., 40:281-289.

California Institute of Technology

Pasadena, California

(Division of the Geological Sciences, contribution no. 552) 